Irena Kraševac

Institut za povijest umjetnosti, Zagreb

\title{
Prva tri djela u fundusu Moderne galerije Društva umjetnosti
}

\author{
Izvorni znanstveni rad - Original scientific paper \\ Primljen - Received 14. 7. 2019. \\ UDK 73/75:[069.9(497.5Zagreb)"190"
}

DOI 10.31664/ripu.2019.43.19

\begin{abstract}
Sažetak
Članak se bavi počecima osnutka Moderne galerije u Zagrebu i stvaranja njenog fundusa. Preispituju se uvriježeni podaci o prva tri djela za zbirku, slici Pred vratima smrti Mirka Račkoga, skulpturi Timor Dei Ivana Meštrovića i reljefu Isus i Marija Magdalena Františeka Bíleka, te se na osnovi arhivskoga gradiva i kataloga izložaba Društva umjetnosti
\end{abstract}

predlaže preciznija kronologija i slijed okolnosti njihove nabave. Djela Meštrovića i Račkoga danas su u stalnom postavu Gliptoteke HAZU, odnosno Moderne galerije, dok je Bílekov drveni reljef u vlasništvu Moderne galerije, na temelju Ugovora izmedu dviju ustanova, pohranjen $u$ depou Gliptoteke HAZU.

Ključne riječi: Društvo umjetnosti, Moderna galerija, Zagreb, izložbe, Iso Kršnjavi, Mirko Rački, Ivan Meštrović, František Bílek

Začetak promišljanja o osnutku Moderne galerije u Zagrebu datira u vrijeme izložbe Prvi hrvatski salon održane u Umjetničkom paviljonu od 15. prosinca 1898. do kraja veljače 1899. godine. U svojim kritičkim osvrtima na izložbu Iso Kršnjavi prvi je javno iznio hipotetski prijedlog da se Umjetnički paviljon prenamijeni u Modernu galeriju, s obrazloženjem: »... prava namjena zgrade bila bi: da se u njoj osnuje gradska galerija modernih slika. Za takovu svrhu ne bi zgrada bila ni preveć lijepa ni preveć skupa, jer se tu radi o trajnom namirenju jedne duševne potrebe naroda, kojoj akademijska galerija sama ne može da udovolji. $\aleph^{1}$ Kršnjavijevu zamisao stvaranja budućeg fundusa potkrepljuje i podatak da je Društvo umjetnosti na toj izložbi kupilo 14 djela, ${ }^{2}$ s nakanom da će »kupljene umjetnine davat dijelom akademijskoj ili gradskoj galeriji modernih slikâ, ako se taka po vremenu osnuje «. ${ }^{3}$

Na tragu te ideje organizator izložbe Društvo hrvatskih umjetnika zatražilo je 28. travnja 1901. godine promjenu svog Pravila za izložbe u Umjetničkom paviljonu pod točkom $10 \mathrm{a}$, prema kojem bi se eventualni višak od poslovne godine namijenio za otkup izloženih djela koja bi činila temelj moderne galerije u paviljonu. ${ }^{4}$

Na izložbi Društva umjetnosti 1902. godine, održanoj također u Umjetničkom paviljonu u sekciji arhitekture, Ivan Kos izložio je skice za adaptaciju paviljona u galeriju. ${ }^{5}$ Kršnjavi je u svom kritičkom ogledu na tu izložbu zapisao: »... Ivan Kos načinio je crtež za hrvatsku galeriju umjetnina. Po tom tlorisu bi se dobro zamisliti moglo proširenje Umjetničkog paviljona u gradsku galeriju slika. ${ }^{6}$ Upravo su te početne godine važne za osvještavanje značaja pokretanja osnutka Moderne galerije u Zagrebu, a krenule su gotovo istodobno iz secesioniranog Društva hrvatskih umjetnika i Kršnjavijeva Društva umjetnosti. Ta se dva društva 1903. godine kompromisno spajaju u Hrvatsko društvo umjetnosti, a koje će u konačnici biti osnivač Moderne galerije.

Premda se 25. obljetnica kontinuiranog rada nakon ponovnog aktiviranja 1879. navršavala 1904 . godine, Jubilarna izložba organizirana je u proljeće 1905 . godine, ${ }^{8}$ a uspjeh koji je postigla ponovno je aktualizirao pitanje osnutka Moderne galerije. Na godišnjoj skupštini Hrvatskog društva umjetnosti, održanoj 17. prosinca 1905. godine, tajnik Artur Schneider izvijestio je da se: »Pitanje osnutka jedne nove moderne galerije umjetnina na način mletačke, bečke i praške počešće javljalo u radu našeg društva. Tako je najzad u proljeću ove godine naše društvo zaključilo, da po mogućnosti i prema svojim skromnim raspoloživim sredstvima doprinese svoj dio do osnutka ovakove moderne galerije. Kako je ostvarenje toga pitanja u daljoj, ali nadamo se u doglednoj budućnosti, tako se i detalji nisu točnije ispitivali i pretresivali. Društvo je naše za ovu modernu galeriju odredilo već tri umjetnine. Od ovih je jednu nabavilo svojim sredstvima. Meštrović je svoju veliku grupu 'Timor Dei', koja je proljetos u Beču veoma pohvalno primljena, poklonio društvu umjetnosti, a 
ovo mu je nadoknadilo samo materijalne izdatke; (isto tako i Račkovu veliku sliku 'Pred vratima smrti'), Bilekov relief 'Isus i Magdalena' primilo je društvo na dar od pokojnoga župnika Stjepana Boroše. Tijem je učinjen prvi korak, a mi se pouzdano nadamo, da će nas u našem nastojanju pomoći i drugi ljubitelji umjetnosti i imućnici. «9 Zanimljivo je da temu osnutka Moderne galerije ne dotiče predsjednik Kršnjavi u svom govoru na skupštini u kojem se isključivo bavi urbanističkim problemom razvoja grada Zagreba. ${ }^{10}$

Vjerojatno se na osnovi toga Godišnjeg izvješća u kojem se pozivalo na »zaključak društva iz proljeća 1905. da doprinese svoj dio osnutku moderne galerije«, uvriježio neprecizan i neutemeljen podatak da je Moderna galerija i osnovana 1905. godine te da su prva tri umjetnička djela koja su ušla u fundus bile sadrena skulptura Timor Dei Ivana Meštrovića, triptih Pred vratima smrti Mirka Račkoga i drveni reljef Isus i Magdalena Františeka Bíleka koja su »nabavljena na Jubilarnoj izložbi Društva umjetnosti održanoj iste godine ${ }^{11}$ Povezivanje tih triju djela s Jubilarnom izložbom dovelo je do preispitivanja tog podatka, jer je u katalogu izložbe zabilježena samo slika Mirka Račkoga, a potraga za argumentima i provjera podataka navela je na revidiranje dosadašnjih činjenica koje povezujemo s počecima Moderne galerije i stvaranja njezina fundusa. ${ }^{12}$

Činjenica je da su na Jubilarnoj izložbi Društva umjetnosti 1905. godine Meštrović i Rački doista prvi put izlagali u Zagrebu. Katalog navodi deset djela Ivana Meštrovića: Studija za spomenik Luke Botića, Gospodjica medicinarka, Moja puca, Skica za Vegin spomenik, Majčina briga, Punctum interrogativum, Curica, Dijete, Mislilac i Conte Ugolino, dok je Rački izložio jednu sliku Na vratima smrti i crteže perom Studije za Danteovu 'Božansku komediju'. ${ }^{13}$ Jubilarnoj izložbi Kršnjavi je posvetio serijal članaka objavljenih u Narodnim novinama, u kojima s neskrivenim ponosom govori o izložbi kao rezultatu djelovanja Društva umjetnosti. ${ }^{14} \mathrm{U}$ Pogledu na razvoj hrvatske umjetnosti u moje doba Kršnjavi ne spominje utemeljenje Moderne galerije u godini u kojoj je objavio taj rukopis (1905.), nego ga zaključuje komentarima na Jubilarnu izložbu izdvajajući Ivana Meštrovića i Mirka Račkog, koji "među mladim umjetnicima uzdižu se visoko«. ${ }^{15}$ Umjetnički potencijal dvojice mladih umjetnika koji su u to vrijeme boravili na školovanju, Meštrović u Beču, a Rački u Pragu, Kršnjavi je zarana prepoznao i pohvalio: »... u [Račkog] je bujna fantazija i mnogo umjetničkog osjećaja, (...) a Meštrović je vrlo jak talenat; upravo genijalan «. ${ }^{16}$

Prvi zasad poznati inventarni popis Moderne galerije sastavljen je prigodom »smjene« 1918./1919. godine kada, nakon Kršnjavija, predsjednikom Društva umjetnosti postaje Dušan Plavšić. ${ }^{17}$ Popisana je društvena imovina u koju je spadala i Moderna galerija »koja imade 69 djela u vrijednosti od po prilici $100.000 \mathrm{~K} .{ }^{18}{ }^{18}$ što se podudara s dokumentom iz Plavšićeve ostavštine. ${ }^{19} \mathrm{U}$ tom su popisu evidentirana i tri spomenuta djela, br. 27. Meštrović, »Timor Dei«, skulptura u sadri; br. 30. Rački »Pred vratima smrti« i br. 46. Moderna češka škola, »Isus na Maslinskoj gori« /darovao župnik Stjepan Boroše/ (sic!).

Antun Jiroušek je 1927. godine objavio jedan od prvih historijata Moderne galerije u kojem je napisao: »K ostvarenju galerijskog pitanja pristupilo se u proljeće godine 1905. pa je društveni tajnik mogao već iste godine na glavnoj skupštini od 17. decembra obavijestiti prisutne članove da je društvo po mogućnosti i prema svojim skromnim raspoloživim sredstvima pristupilo izvršivanju svoga zaključka na taj način što je za Modernu galeriju odredilo tri umjetnine. Bile su to: Meštrovićev 'Timor Dei' s kojom je kompozicijom baš u to vrijeme nadobudni umjetnik stekao u Beču opću pohvalu, a koju je grupu Meštrović poklonio društvu umjetnosti uz naknadu samo faktičnih materijalnih izdataka; zatim veliki triptihon 'Pred vratima smrti' koju je sliku Rački naslikao radeći tada na praškoj akademiji u atelijeru majstora Bukovaca, i napokon od češkog skulptora Bileka u drvu rezani reljef 'Isus i Magdalena', što ga je primilo društvo umjetnosti na dar od pokojnoga zagrebačkog župnika dr. Boroše. S ovim trima umjetninama udareni su temelji današnjoj modernoj galeriji koja je do danas ostala na brizi svoga osnivača i s kojom dakako dosljedno tome ima pravo raspolaganja samo Hrvatsko društvo umjetnosti u Zagrebu. ${ }^{20}$

Ivo Šrepel, u povodu otvorenja Moderne galerije u Palači Vranyczany (tada zgradi Hrvatskog seljačkog doma) 1934. godine, objavljuje članak u kojem navodi da je ideja o osnivanju jedne umjetničke galerije »uzeta u ozbiljno razmatranje tek u vrijeme Kršnjavoga, koji je na jednoj sjednici Društva umjetnosti predložio konkretan plan za ostvarenje Moderne galerije. Galerija je zaista osnovana što darovima, a što otkupljenim radovima, pa među prvima u njoj nalazimo djela Vlaha Bukovca, mladenačke radove Ivana Meštrovića, simpatične pejzaže Ferde Kovačevića i Nikole Mašića, biste Valdeca i Frangeša, kompozicije Bele Čikoša-Sessije i Mirka Račkoga, radove Otona Ivekovića, Mencija C. Crnčića, Tomislava Krizmana i Roberta Auera, sve same danas vrlo zanimljive dokumente naše prošlosti. «21 Šrepel u svome drugom osvrtu, objavljenom 1938. godine, navodi podatak: »Prva tri rada ove danas velike i lijepe zbirke bili su: sadreni odljev Meštrovićeve grupe 'Timor Dei', triptihon slikara Mirka Račkog 'Pred vratima smrti' i relief u drvu Františega Bileka 'Isus i Magdalena.'«22 Kasniji će se autori vezati za taj navod i pridodati da su djela izlagana na Jubilarnoj izložbi Društva umjetnosti 1905. godine. ${ }^{23}$

Uvidom u katalog Jubilarne izložbe i kritičke objave u periodici, isključeno je sudjelovanje Meštrovića s djelom Timor Dei i Františeka Bíleka na toj izložbi, a potvrđeno je izlaganje slike Pred vratima smrti Mirka Račkoga. Razmatrajući podrobnije izložbe i događanja u 1903., 1904., 1905. i 1906. godini, nameće se ponešto izmijenjena kronologija, što ćemo potkrijepiti slijedom pojavljivanja spomenuta tri ključna djela na izložbama i u arhivskim dokumentima te revidirati činjenice vezane uz njihovu nabavu za fundus Moderne galerije.

\section{Mirko Rački, Pred vratima smrti, Prag, 1904.}

Nakon početnih slikarskih pokušaja kao samouki umjetnik i neuspjeha pri upisu na bečku likovnu akademiju, Mirko Rački dvije godine pohađa privatnu umjetničku školu Strehblow u Beču u kojem upoznaje Vlahu Bukovca. Na njegov poziv početkom 1904. upisuje drugi semestar druge godine Opće slikarske škole na Akademiji likovnih umjetnosti u Pragu. ${ }^{24}$ 


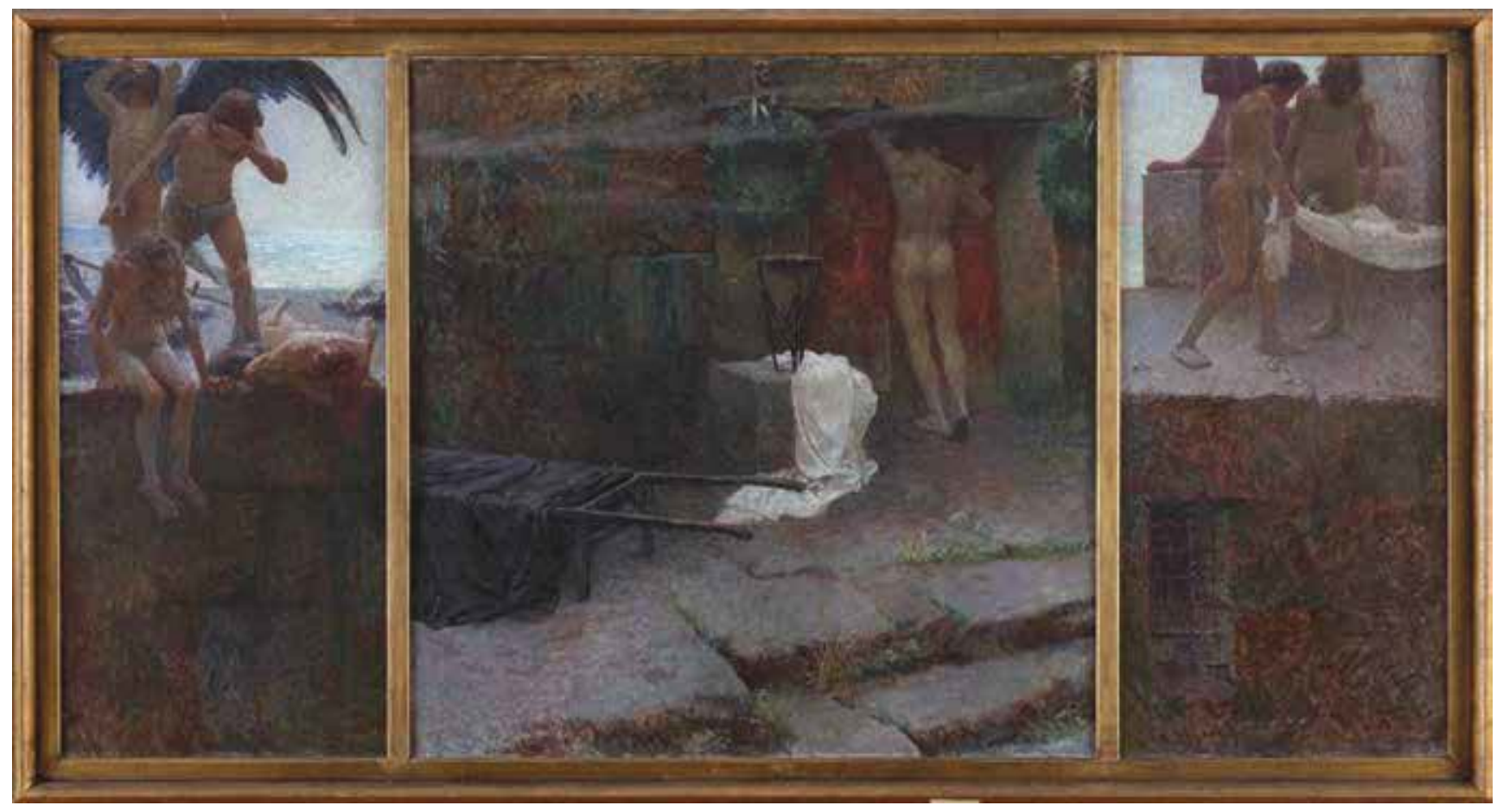

1. Mirko Rački, Pred vratima smrti, Prag, 1904., ulje na platnu, $89 \times 176$ cm, signirano: Prag 1904 Mirač, Moderna galerija, Zagreb, MG-937 Mirko Rački, At the Gate of Death, Prague, 1904, oil on canvas, $89 \times 176$ cm, signed: Prag 1904 Mirač, Modern Gallery, Zagreb, MG-937

Bukovac ga potom preporuča Kršnjaviju za stipendiju, odnosno financijsku potporu koju mu Društvo umjetnosti dodjeljuje tijekom iste godine, a Rački se obvezao potporu uzvratiti slikom. Iz pisma Mirka Račkoga Kršnjaviju iz Praga saznajemo i da je Rački Kršnjaviju na uvid najprije poslao crtež i skicu ${ }^{25}$ (sl.2), koju je ovaj pohvalio te naručio da izradi sliku u tehnici ulja na platnu za Društvo umjetnosti (sl. 1). Kršnjavi piše Račkome 19. travnja 1904. godine: »Vaše skice su mi se vrlo svidjele, a i umjetnicima. Poslao sam Vam 20 Kruna od svoje strane, a društvo će Vam poslati 30 Kruna. Izvolite izraditi kao crtež na način kakova je skica onu ideju, gdje mladić hoće da razbije vrata groba. Uzmite model. Kad nam taj crtež pošaljete, društvo će Vam po mogućnosti honorirati, a 30 Kruna što Vam sada šaljem smatrajte a conto... $\ll^{26}$ Da je došlo do izravne narudžbe, svjedoče podaci u Knjizi računa Društva umjetnosti u kojoj je zabilježena isplata »društvene potpore« Mirku Račkom, kao i trošak dovoza njegove slike iz Praga. ${ }^{27}$ Saznajemo također da je Rački sliku zgotovio za studentsku izložbu na praškoj Akademiji u lipnju 1904. godine i u rujnu je otposlao za Zagreb. ${ }^{28}$ Riječ je nedvojbeno o slici Pred vratima smrti, u čijem je središnjem dijelu triptiha mladić koji stoji okrenut leđima pred crvenim vratima, u sredini je kubus na kojem je žara i odloženo bijelo platno, a lijevo je mrtvačka nosiljka prekrivena crnim plat-

2. Mirko Rački, Pred vratima smrti (studija), Prag, 1904., ulje na kartonu, 50,5×99,5 cm, signirano: Mirač Prag 904, Muzej suvremene umjetnosti, Zbirka Benko Horvat, Zagreb

Mirko Rački, At the Gate of Death (study), Prague, 1904, oil on cardboard, $50.5 \times 99.5 \mathrm{~cm}$, signed: Mirač Prag 904, Museum of Contemporary Art, Benko Horvat Collection, Zagreb nom. U lijevom dijelu slike trojica nagih muškaraca naginju se nad ponorom, dok četvrti krilati mladić, pogleda uperenog u nebo, zdvojno drži ruke na glavi. Na desnoj slici triptiha dvojica muškaraca slažu bijelo platno, na kamenom kubusu je sfinga pogleda uperena u morsko plavetnilo, koje u svojoj horizontali uravnoteženo spaja lijevu i desnu stranu triptiha u cjelinu slikarske kompozicije. Inspiraciju za temu slike vezujemo uz smrt djevojke koju je Rački romantično volio, kako je prenio u pismu Kršnjavom: "'Nju' su odnijeli na ona teška bakrena vrata, koja su se za njima teškim bravama zamandaljena zatvorila. 'Njega' nijesu pustili. Pred čvrstim vratima stoji on - čovjek slab i nemoćan. Uzalud drma on s njima - uzalud moli - nitko ne haje za njegove riječi. Ili nije tako. Čini se ipak, da ga netko čuje - ali taj mu se ruga, taj ga ismjehava, a to ga boli - neizmjerno boli - a on u svojoj nemoćnosti ne može - nego, da si gorkom suzom dokaže - svoju bijedu. Tamo kamo su odnijeli 'nju' tamo buči more jugovine svojim vječnim valovima. Imali bi prikazati

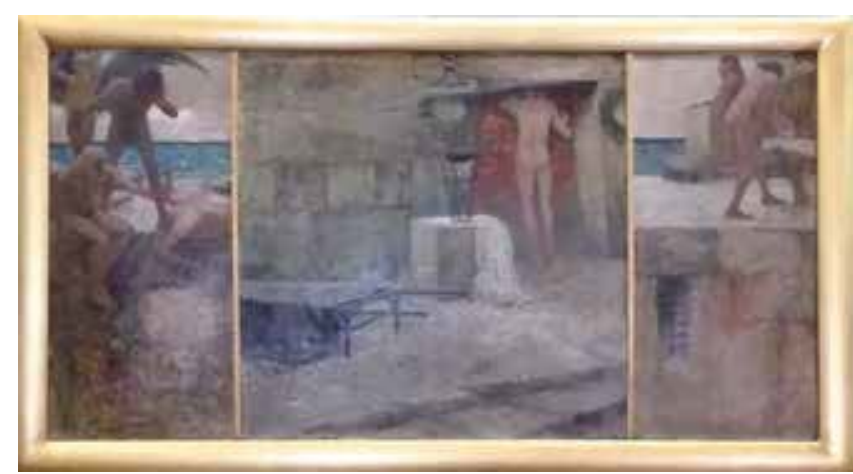


- malenog čovjeka pred golemom silom smrti. Oni s lijeve strane, ono su demoni, koje čovjek nosi u svom biću i koje si je sam izabrao, kako veli Platon. Oni su bičevi neprekidne pruge - što je čovjek ćuti u vlastitoj slabosti. «29

Slika Mirka Račkoga Pred vratima smrti jedino je djelo od tri pretpostavljena koje možemo sa sigurnošću povezati s izlaganjem na Jubilarnoj izložbi Društva umjetnosti, ${ }^{30}$ a zahvaljujući novčanoj potpori koju je Društvo slalo Račkom u Prag za nastavak studija i za sliku, ostalo je u vlasništvu Društva koje ga poslije uvrštava u novoformiranu zbirku Moderne galerije. Put koji je slika prošla, od početnih studijskih crteža i predslike, izlaganja na godišnjoj studenskoj izložbi na Akademiji likovnih umjetnosti u Pragu 1904. do Jubilarne izložbe u Umjetničkom paviljonu u Zagrebu 1905. godine i ulaska među prve umjetnine u fundus Moderne galerije potkrijepljen je autentičnim izvorima, pismima Mirka Račkoga i Ise Kršnjavija, te Knjigom računa Hrvatskog društva umjetnosti.

\section{Ivan Meštrović, Timor Dei, Beč, 1903. - 1905.}

Pretpostavljamo da se prvi susret Ivana Meštrovića sa Isom Kršnjavijem dogodio u Beču krajem 1903. ili početkom 1904. godine. ${ }^{31} \mathrm{O}$ svom susretu s mladim Meštrovićem Kršnjavi je izvijestio na Odborskoj sjednici Društva umjetnosti 14. lipnja 1904. i založio se da se »kiparu Meštroviću koji radi loših materijalnih odnošaja strada, pruža pomoć time da se kod njega uz cijenu od 800 kruna naruči jedan mramorni kip, koji će onda društvo pokušati dalje prodati.« Poslije podulje rasprave o tom premetu, primljen je prijedlog blagajnika Hermana Bolléa po kojem se »odustane od nakane da se kod Meštrovića naruči radnja već se Meštroviću bez ikakve daljne obveze doznačuje pripomoć u iznosu od 200 Kruna." 32 Toga će se Kršnjavi prisjetiti i 1917. godine kada je počeo trpjeti napade zbog "nedjelotvornosti Društva umjetnosti« kojima je bio izložen. »Meštroviću kad je u najvećoj bijedi u Beču živio, pomogli smo odliti sadru Timor Dei. Stanovao je u nekoj niskoj maloj sobici, da je ta grupa sizala do plafona. $\aleph^{33}$ Zahvaljujući mogućnosti koju mu je pružio Kršnjavi putem Društva umjetnosti, to je monumentalno djelo Meštrović prvi put izložio na proljetnoj izložbi bečke Secesije 1905. godine, koja se pak vremenski poklapa s trajanjem zagrebačke Jubilarne izložbe. ${ }^{34}$ (sl. 3.)

Na temelju iznesenih navoda potkrijepljenih arhivskim izvorima, Meštrović je rad na tom monumentalnom slobodnom reljefu započeo već zimi 1903./1904. godine jer ga Kršnjavi zatiče u »nekoj niskoj maloj sobici«. Detaljniju kronologiju nastanka djela, njegova lijevanja, izlaganja i dopreme u Zagreb, saznajemo iz pisama Ivana Meštrovića i Ise Kršnjavija. ${ }^{35}$ Djelo Timor Dei spominje se u Meštrovićevu pismu od 4. veljače 1905. godine u kojem se osvrće na Kršnjavijev boravak u Beču i spominje: »Onu veliku grupu nijesam još dovršio no mislim koncem ovoga mjeseca. Sada kad sam gornji dio još nadodao puno se bolje čini jer se je tijem čitava stvar popunila. Zadnje vrijeme su mi se iz 'Secesije' javili neka se pripravimo za proljećnu izložbu, pak sam im moro obećati, te baš radi toga ne znam kako će mi biti glede Zagreba. Njihova se izložba otvara drugom polovicom ožujka, a trajati

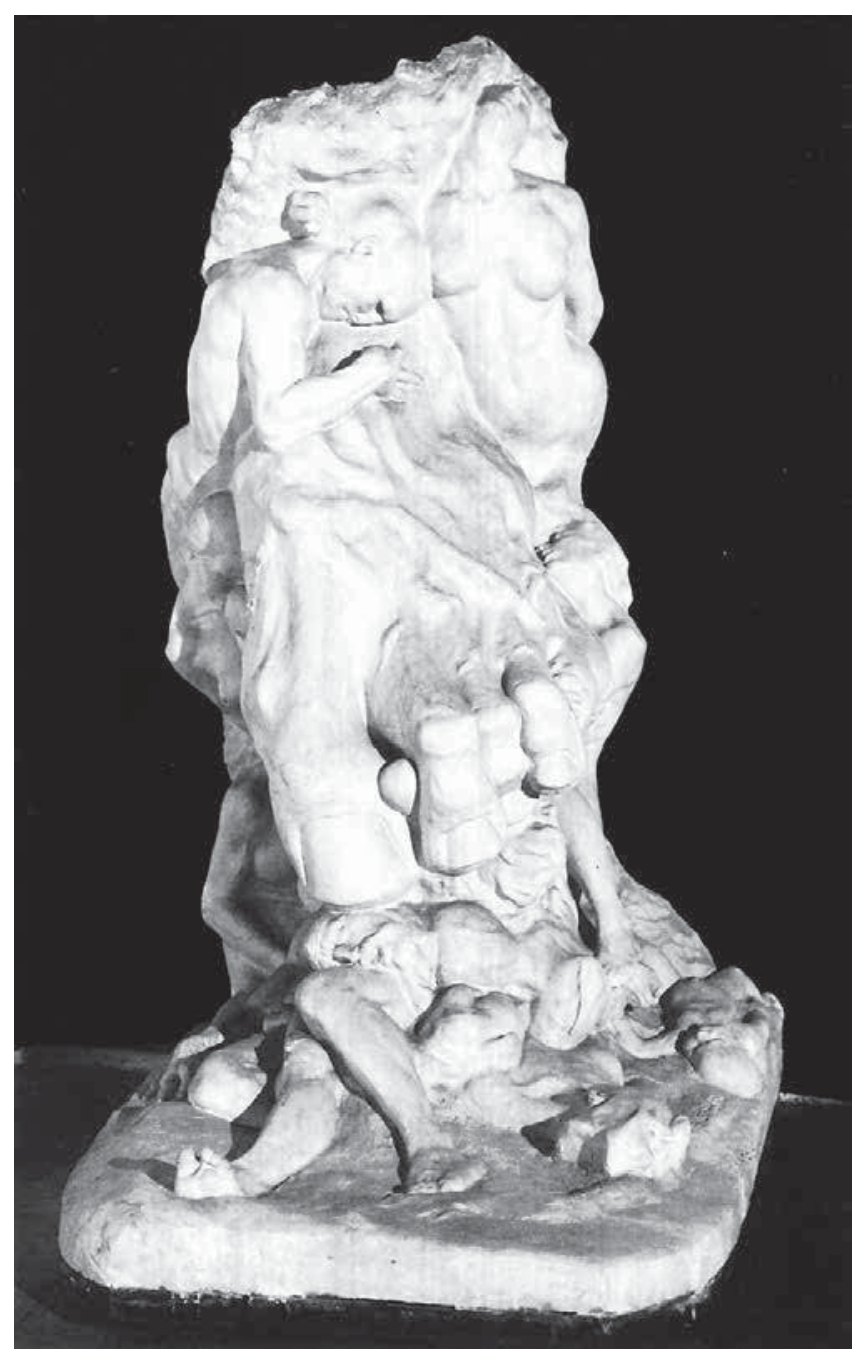

3. Ivan Meštrović, Timor Dei, Beč, 1903.-1905., signirano: MEUTPOBIЂ, sadra, $200 \times 145 \times 120 \mathrm{~cm}$, Pohrana u Gliptoteci HAZU, Zagreb, MZP-732

Ivan Meštrović, Timor Dei, Vienna, 1903-1905, signed: МЕШТРОВIT, plaster, $200 \times 145 \times 120 \mathrm{~cm}$, stored at Glyptotheque HAZU, Zagreb

će do 15. svibnja. Mislim da će na taj način biti prekasno za našu izložbu a da bi mi ona velika skupina koju tamo izložit kanim prispjela. A što Vi mislite i jeste li toga mnjena da na svaki način u 'Secesiji' izložim? « Kršnjavi mu odgovara: »(...) Meni se vidi da će dovoljno biti ako Vašu veliku grupu u Secesiji izložite, pa ako Vaše druge stvari ovamo pošaljete (na Jubilarnu izložbu, op. a.). Sa velikom grupom držim da ćete u Beču imati sreće. Ovdje bi Vam kod nekoliko nas našla priznanje ali praktične koristi Vam otud nebi bilo nikakove, dok ćete manje stvari ovdje laglje prodati... « te ga savjetuje da na proljeće »ne smije faliti« na izložbi Secesije i gotovo proročki zaključuje: »Ondje je otvoren put vašoj karieri. « Meštrović u pismu Kršnjavom od 17. veljače 1905. spominje: »... velika mi grupa još nije sasvim gotova, jer sam nekoje svari promjenijo i nešto nadopunijo, ali se nadam za nekih 8-9 dana podpuno svršit. « U pismu 25. veljače 1905. potvrđuje dovršetak: »... također [sam] moju veliku grupu svršio. (...) Velika će mi se grupa počet sjutra odljevati. Neznam što će onda biti, čime 
li ću mu platit. (...) Kad bi mi društvo ili akademija samo troškove platili poklonio bi 'Timor dei' muzeju, a onda ako bi se moje prilike poboljšale mogo bi eventualno u kakom drugom materialu izvesti. Stoga Vas molim ako vi nalazite da stvar ima smisla da izvolite istu ideju priporučiti.« Dana 15. ožujka 1905. godine Meštrović piše Kršnjaviju: »Ona velika mi se grupa jučer pri transportu u Secesiju na 6 komada skršila, pošto je bila sadra mokra, sad ne znam kako će stvar svršiti, «a 22. ožujka 1905. javlja dopisnicom: »... mogu Vam javit, što inače jučer nijesam mogao da je moja velika radnja 'Timor Dei' bila s oduševljenjem u Secesiji primljena. Sad ne znam kako će ispasti čitava stvar... « Dva dana zatim piše: »Kako sam vam već javio moja je vel[ika] radnja u Secesiji izložena, koja se baš danas otvorila, pa mi se čini iako se neće podpuno možda Vaše riječi ispuniti, da ću ja sasvim 'led' probiti. (...) Meni su dali posebnu sobu gdje je jedino moja radnja, a izrazili su se s velikim oduševljenjem. «Desetak dana kasnije javlja: »... Imate pravo da će mi ova velika grupa doista koristiti iako možda neće s njome sasvijem led probiti, jer je ovdje na sjeveru tvrd, a ovo ću ipak bar više poznanstava dobiti. Jučer sam dobio pismo iz Münchena, gdje me moli redakcija od Kunst für Alle da je ovlastim da istu stvar u njihovoj novini na više načina reproduciraju. Od The Studio isto. « Kršnjavi 16. svibnja 1905. godine piše Meštroviću u Beč da mu brzojavno šalje 200 kruna da riješi pitanje stana i atelijera: »(...) Pošaljite mi račun Sadra za odljev Vaše grupe Timor dei (...) Kad ćete poslati grupu? Mi ćemo ju staviti u Modernu galeriju koju ćemo napose otvoriti. Kad bude u Zagrebu nastojat ćemo da nadjemo benefaktora koji će ju dati u kamenu isklesati. - Što bi stajao kamen? «na što Meštrović odgovara: »Jako mi je ugodno čuti da će moja grupa Timor dei u naš Zagreb biti spremljena kako sam ju i želio netom sam ju počeo. Saljevaču sam danas piso glede računa, pa će Vam ga ovih dana i poslati. ${ }^{36}$ Po završetku izložbe u Secesiji, skulptura je spakirana i otpremljena za Zagreb, o čemu Meštrović izvještava u pismu od 15. lipnja 1905. godine: »Tek danas sam činio grupu zapakirati, jer mi nije prije bilo moguće, pošto je izložba sve do jučer trajala, a prije mi ju na nikakav način nijesu mogli prepustiti. Biti će odmah sad odpremljena, pa je najduže za 5 dana tamo." Da je u transportu ponovo došlo do problema i oštećenja, doznajemo iz Meštrovićeva pisma Kršnjaviju od 3. srpnja 1905. godine: "Vaše su me obje karte ubile u pojam, gdje mi pišete da se moja grupa potrla. Ja ne pojmim kako se to moglo dogodit da se je gornji dio skašio - a dolji zar je čitav? Dobro je da ste stvar u sanduku ostavili, dok ja tamo dodjem, a mislim okolo 17 ovoga - ako mi Bog novca pošalje. Potrtu grupu ja ću dakle kad tamo dodjem podpunoma popravit. «77 Tijekom srpnja 1905. godine Meštrović boravi u Zagrebu i tada je primio dodatnih 270 kruna za kompoziciju Timor Dei. ${ }^{38}$ Narodne novine zabilježile su njegov dolazak u Zagreb: "Ovamo je stigao iz Beča naš mladi umjetnik g. Ivan Meštrović, kipar, te je već popravio veliku grupu 'Timor dei', koja se je bila putem skrhala. Ta će grupa biti provizorno smještena u obrtnom muzeju «. ${ }^{39}$

Ta velika skulpturalna grupa prvi je put izložena u Zagrebu na izložbi Hrvatskoga društva umjetnosti u Umjetničkom paviljonu u rujnu i listopadu 1906. godine, zajedno s druga dva Meštrovićeva reljefa Zidanje Skadra i Umjetnik naroda moga..$^{40}$ Djelo koje je pobudilo pozitivne ocjene bečkih kritičara i postalo jedno od ključnih radova kiparova ranog razdoblja ${ }^{41}$ dočekano je sa zanimanjem u Zagrebu. Potvrdu nalazimo u Kršnjavijevu kritičkom osvrtu na izložbu: »... Timor dei pokazuje još upliv Rodinov (...) izraz je vrlo pesimističnoga shvaćanja ljudske sudbine. Nesmiljena sudbina mrska sve živo, mlado, staro, muško i žensko, pa ipak se uzvine ljudska duša, da onu silu, koja ljudstvo tamani, ljubi, da je puna nade u molitvi k njoj uzdiže. To je misao, koju Meštrović izražava. Schopenhauerski pesimizam. Taj pesimizam samo vidi smrt, a ne vidi rađanje i život. Protuslovi sam sebi, jer ipak naviješta bar vječni život ljudstva, a propast tek pojedinih individua. Otkuda Meštroviću tako okrutno, pesimističko shvaćanje, to ne pitamo; tek moramo izreći da je ta misao velikom snagom izražena. Meštrović modelira lahkoćom i sigurnim umijećem ljudska tjelesa, prikazuje u svakom liku i pokretu čuvstva vrlo dobro. U kolosalnoj nozi izražena je energija i velika snaga. S gledišta plastične ljepote ipak se može prigovoriti, da je cijela kompozicija nejasna u toku crta, više proračunana za slikovni učin, tako da bi čitava kompozicija bila mnogo zgodnija za bakropis, negoli za plastičnu grupu. « ${ }^{42}$ Godinama poslije Kršnjavi se još jednom osvrnuo na Meštrovićevo djelo kao odgovor na članak Svetozara Rittiga: »(...) U modernoj galeriji Društva umjetnosti, zanimljiv je kip Meštrovićev. Rodin je modelirao Božju ruku, Meštrović Božju nogu koja nesmiljeno gazi i gnječi ljude kao da su gusjenice. « ${ }^{43}$

Historijat nastanka djela u skučenom bečkom atelijeru, odlijevanja i pojavljivanja na izložbama Secesije 1905. i Hrvatskog društva umjetnosti 1906. godine, detaljno iščitavamo iz korespondencije Kršnjavija i Meštrovića, koja ujedno ukazuju i na politiku nabave djela za buduću Modernu galeriju sredstvima Hrvatskoga društva umjetnosti kao i u slučaju slike Mirka Račkoga, putem izravnog potpomaganja mladih hrvatskih umjetnika na školovanju na likovnim akademijama u Pragu i Beču.

Neosporna je Kršnjavijeva savjetodavna uloga i snažan utjecaj koji je postigao ponudivši im Danteov spjev Božanstvena komedija kao vrelo tematskih inspiracija, a koje će obojica umjetnika zdušno prihvatiti. Literarni će ih predložak inspirirati za izrazito simbolistička likovna djela na tematskoj podlozi smrti koja je bila vrlo česta upravo na prijelazu stoljeća. ${ }^{44}$

Fratišek Bílek, Isus i Marija Magdalena, Prag, 1901. - 1902.

Aktivnosti hrvatskih umjetnika na međunarodnom planu na prijelazu 19. u 20. stoljeće razvile su značajnu mrežu suradnje putem gostujućih izložaba. Zahvaljujući kontaktima s češkim umjetnicima, organizirane su dvije izložbe u suradnji Društva umjetnosti i Društva Mánes. Hrvatski su umjetnici 1903. godine gostovali u Pragu, u izložbenom paviljonu češkog Umjetničkog društva Mánes, a uzvratna je izložba čeških umjetnika priređena u Umjetničkom paviljonu, u Zagrebu 1904. godine. ${ }^{45}$ Bila je to ujedno i najveća smotra tada najznačajnijih čeških modernih umjetnika sa znatnim udjelom kipara, među kojima se ističe František Bílek koji je, prema podatku u katalogu, izložio devet djela. ${ }^{46}$ Izložba je pobudila 
veliko zanimanje Ise Kršnjavija koji u nizu kritičkih osvrta vrlo detaljno analizira pojedine umjetnike i njihova djela, kao i cjelokupno značenje nastupa čeških umjetnika u Zagrebu. ${ }^{47}$ Kršnjaviju se djelo češkog kipara očito vrlo svidjelo, jer ga u svom prvom kritičkom osvrtu na izložbu društva Mánes izdvaja: »Od svih umjetnina, što su ih Česi izložili, najjače i najdublje čuvstvo vidim u radnjama Fr. Bíleka, br. 5 do 13. «8 $^{48}$ Drugi kritički osvrt posvećen isključivo kiparima započinje Bílekom, te ističe upravo prikaz »Magdalene kao vizionarke, a Isusa kao čovjeka patnika, ne - kao Boga i čovjeka. S jedne strane dakle vjera u vječni sastanak, a s druge strane beznadni pesimizam. «9 Bio je to Kršnjavijev pokušaj pronicanja $u$ duboko simbolistički sadržaj tog djela. U drugom, proširenom izdanju kataloga, zahvaljujući opisu uz naslov, moguće je identificiranje Bílekova reljefa izloženog pod kataloškim brojem 7. Magdalena: »Magdalena dolazi ujutro u vrt, gdje je sahranjen Isus. Grob je otvoren. Isus je uskrsnuo. On stoji sa strane kraj Magdalene pa je takne rukom. Ona gleda preda se u oblake. Umjetnik je htio prikazati, da Magdalena ne vidi Isusa, nego ga osjeća. Pod slikom na okviru su nejasne slike ranjenih ruku. To su uspomene Magdalenine na muku Isusovu. Relief od drva bojadisan žganjem, odredjen je bio za crkvu gotskog stila. $\aleph^{50}$ Opis odgovara reljefu u drvu koji se ubraja u tri prva djela za Modernu galeriju. ${ }^{51}$ (sl. 4.)

Prema podatku iz Zapisnika odborske sjednice Društva umjetnosti, održane 28. listopada 1903. godine, doznajemo da je to Bílekovo djelo već otprije postojalo u Zagrebu. Naime, »Gdja Neureuther poklonila je župnoj crkvi sv. Marka relief F. Bileka 'Magdalena' «, a tadašnji župnik Stjepan Boroša poklonio ga je Društvu umjetnosti. ${ }^{52}$ Podatak iz kataloga izložbe 1904. godine, da je djelo namijenjeno gotičkoj crkvi, možemo povezati s činjenicom da je nedugo prije toga bila dovršena obnova crkve sv. Marka na Gradecu, kao prva sveobuhvatna historicistička stilska restauracija na području tadašnje Banske Hrvatske. ${ }^{53}$ Iso Kršnjavi bio je detaljno upoznat s tijekom obnove crkve, u čiji (neo)gotički interijer Bílekov reljef nije bio ukomponiran, te ga prihvaća za Društvo umjetnosti koje ga izlaže na izložbi društva Mánes u Zagrebu 1904. godine i pohranjuje za fundus buduće Moderne galerije. Na osnovi podataka iz Zapisnika možemo zaključiti da je od pretpostavljena tri djela, upravo Bílekov drveni reljef prva ciljano zaprimljena umjetnina i to već koncem 1903. godine.

Artur Schneider, tajnik Društva umjetnosti, u zapisniku Odborske sjednice iz 1903. zapisao je prezime donatorice, izvjesne "gospođe Neureuther «. U opširnom tekstu Filipa Davidovića Marušića o Františeku Bíleku, objavljenom u časopisu Život 1900. godine, nailazimo na podatak da je kiparovo djelo Podobenstvív velkého Západu Čech (Alegorija velikog pada Češke) »vlasničtvo gdje. M. P Neureutterové. "54 Riječ je o Maruši Pavli Neureutterovoj, značajnoj osobi češkoga javnog života na prijelazu 19. u 20. stoljeće, podupirateljici mladih književnika i likovnih umjetnika. Neureutterova je bila u intenzivnom kontaktu i s hrvatskim studentima $\mathrm{u}$ Pragu koji su rado navraćali u njenu kuću, a sudjelovala je na obilježavanju stote godišnjice rođenja Antuna Mihanovića, autora Lijepe naše, koju su 1896. priredili Hrvati koji su tada živjeli u Pragu. ${ }^{55}$ Konkretniji podaci o njezinim vezama

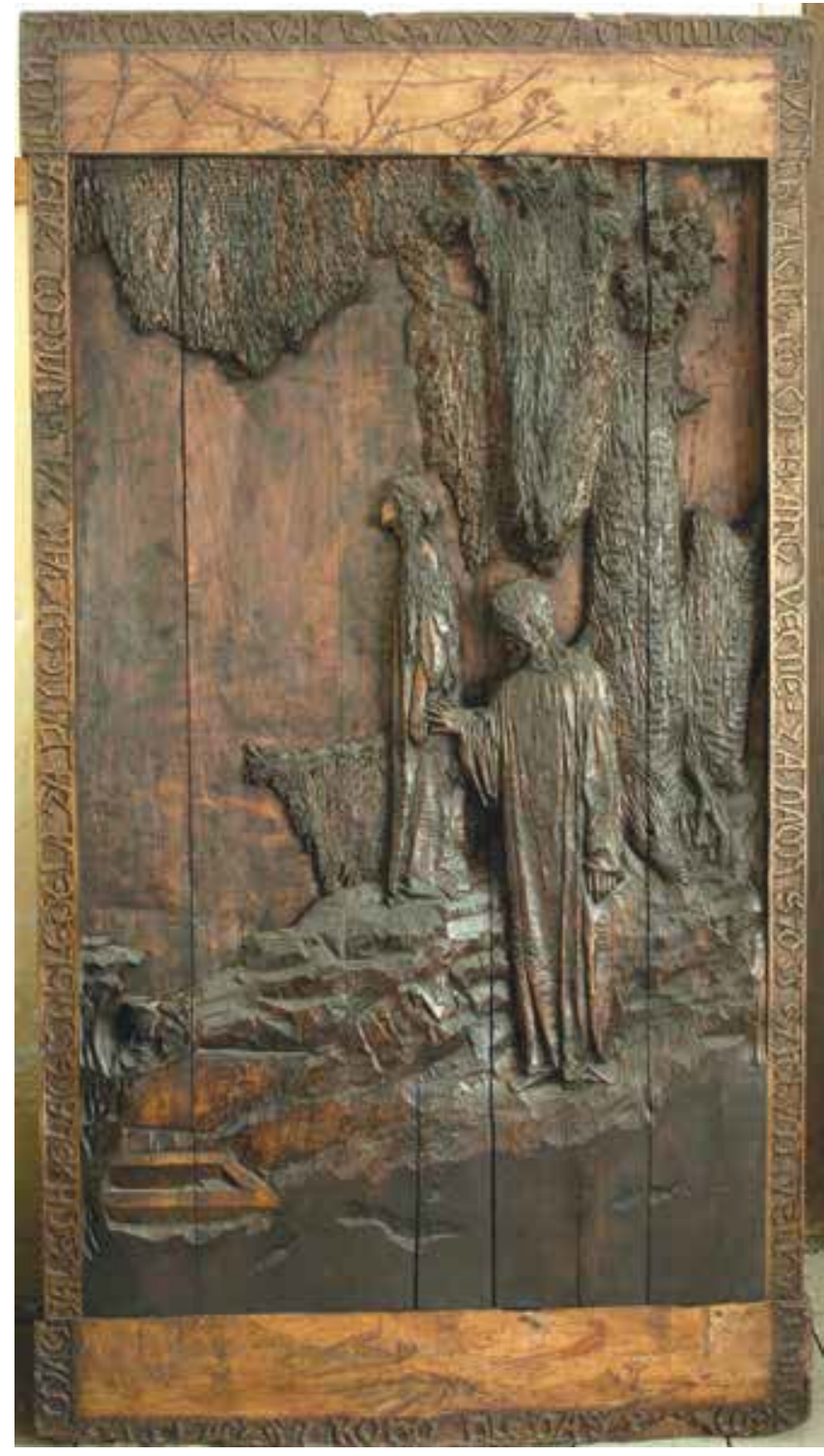

4. František Bílek, Isus i Marija Magdalena, 1901.-1902. (?), drvo, $196 \times 108 \mathrm{~cm}$, Moderna galerija, Zagreb, MG-1325; Pohrana u Gliptoteci HAZU, Zagreb, G-MZO-1185

František Bílek, Jesus and Mary Magdalene, 1901-1902 (?), wood, $196 \times 108 \mathrm{~cm}$, Modern Gallery, Zagreb, MG-1325; stored at Glyptotheque HAZU, Zagreb, G-MZO-1185

s kiparom Bílekom i donacijom njegova djela za crkvu sv. Marka u Zagrebu zasad su nepoznanica.

Reljef Isus i Marija Magdalena pripada razdoblju umjetnikova stvaralaštva koje je obilježeno intenzivnom preokupacijom religioznim temama. Sredinom 1890-ih Bílek se priključuje grupi čeških katoličkih intelektualca i umjetnika poznatoj kao Katolickà moderna, koje će potaknuti integriranje tradicionalnih kršćanskih vrijednosti i moderne umjetničke kreacije. ${ }^{56} \mathrm{U}$ tom će periodu nastati brojna djela snažne simbolističke interpretacije Kristološkog ciklusa, među kojima i reljef u patiniranoj sadri Vrtlar naše Gospe, 1897. godine (sl. 5), kao izravan predložak drevnom reljefu Isus i Marija Magdalena. ${ }^{57}$ Slične reljefe mistično-religiozne tematike snažnoga simbolističkog naboja, koje motivski i 


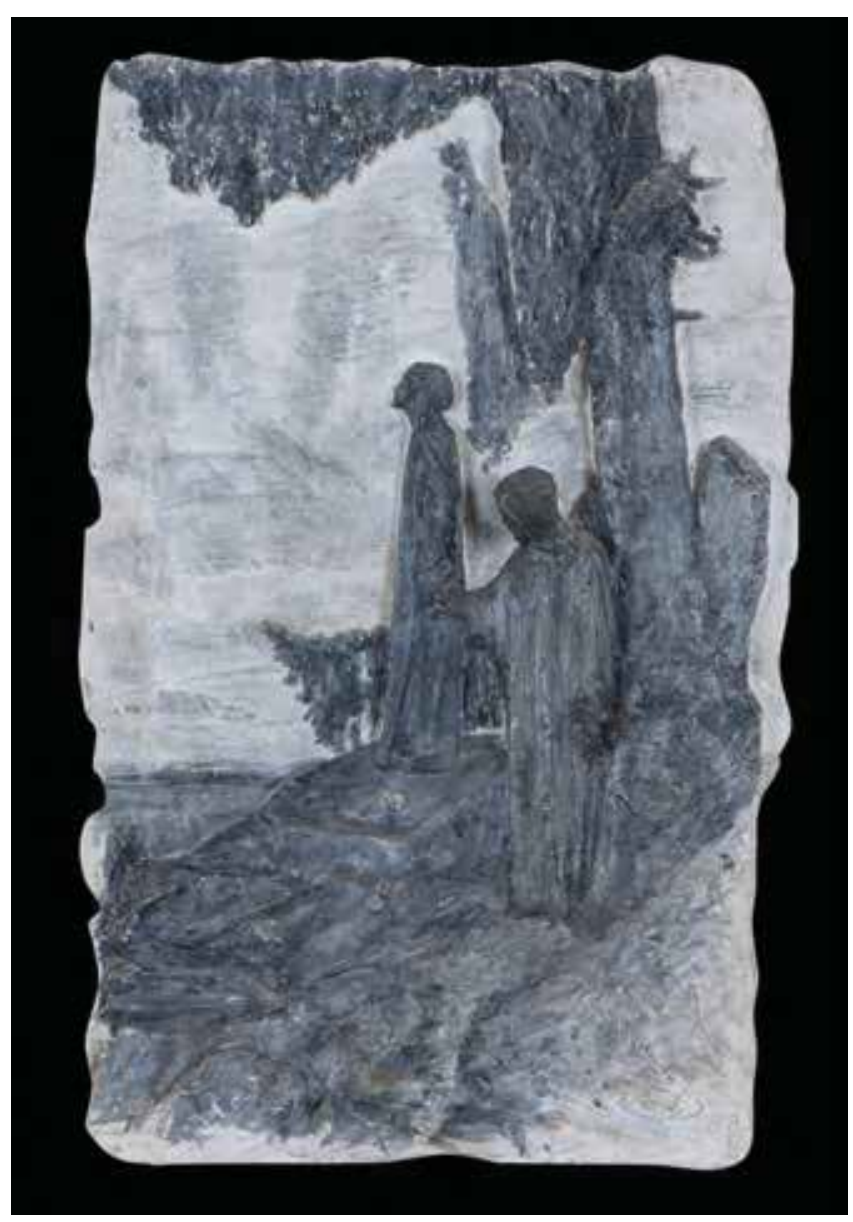

5. František Bílek, Vrtlar naše Gospe, 1897., crno patinirana sadra, $110 \times 55 \mathrm{~cm}$, Galerija Grada Praga, P - 1409, Arhiv Galerije Grada Praga František Bílek, Gardener of Our Lady, 1897, black patinated plaster, $110 \times 55 \mathrm{~cm}$, Municipal Gallery Prague, P - 1409, Archive of the Municipal Gallery Prague

stilski povezujemo s tim, umjetnik je izradio uglavnom u razdoblju od 1897. do 1903. godine. Karakteristične su i poruke ispisane u okvirima drvenih reljefa u tipografiji koju je Bílek oblikovao. ${ }^{58} \mathrm{Za}$ razliku od slobodno komponiranoga crno-patiniranog sadrenog reljefa, drveni je integriran $u$ pravokutni okvir duž kojeg je urezana elegična poema koja dodatno tumači prizor: Co hledaš? Koho hledáš? Magdalena plačící, hleděla za Pánem jak za sluncem zapadlým, - jak čověk, jak lítostivost za minulostí svoju blahou; co on - blaho věčné - za námi stojí s tichým velkým slovem (...) (dalje nečitko). ${ }^{59}$

Na temelju navedenih izvora pratimo i različite nazive pod kojima se to djelo pojavljuje. Prvi spomen je u Zapisniku odborske sjednice Društva umjetnosti 1903. godine: „Gđa Neureuther poklonila je župnoj crkvi sv. Marka relief F. Bileka 'Magdalena' «. Isti naziv je i u katalogu izložbe društva Mánes u Zagrebu 1904. godine. U godišnjem izvješću Društva umjetnosti za 1905. stoji: »Bilekov relief Isus i Magdalena primilo je društvo na dar od pokojnog župnika Stjepana Boroše. «U inventarnom popisu iz 1918./1919. godine autor djela je nepoznat te se spominje Moderna češka škola (!), uz naziv djela »Isus na Maslinovoj gori«. Antun Jiroušek 1927. godine spominje podatak o tome djelu uz ime njegova autora i donatora: »od češkog skulptora Bileka u drvu rezani relijef Isus i Magdalena, što ga je primilo društvo umjetnosti na dar od pokojnoga zagrebačkog župnika dr. Boroše «, ${ }^{60}$ dok Ivo Šrepel u svom osvrtu na povijest Moderne galerije objavljenom 1938. godine također izrijekom spominje reljef $u$ drvu Isus i Magdalena Františeka Bíleka. ${ }^{61}$

U inventarnom popisu Moderne galerije iz 1940. pod kataloškim brojem 170 zapisano je: »Frant Bilek, Krist, drvo reljef«, a isti navod ulazi i u Inventarnu knjigu započetu 1947. godine ${ }^{62}$ Pod istim nazivom pojavljuje se u Inventarnoj knjizi pohrane Gliptoteke HAZU, s napomenom da je 1954. godine djelo preseljeno u depo Gliptoteke. Nakon dugog niza godina u kojima nije pobuđivalo zanimanje struke, Bílekov reljef zatražen je za retrospektivnu izložbu u Pragu 2000. godine, na kojoj nije bio izložen, vjerojatno zbog brojnih oštećenja koja su u međuvremenu nastupila. ${ }^{63} \mathrm{U}$ novije je vrijeme bio očišćen i izložen pod nazivom Isus i Marija Magdalena zahvaljujući istraživanju kustosice Đurđe Petravić, koja ga ikonografski detaljnije iščitava i pokazuje na izložbi stranih kipara i medaljera iz fundusa Moderne galerije 2014./2015. godine, nakon čega se ponovo vraća u depo Gliptoteke.

Rekapitulirajući slijed nabave triju djela, možemo zaključiti je je doista prvo djelo koje je Društvo umjetnosti zaprimilo za budući fundus Moderne galerije Bílekov reljef koji je župnoj crkvi sv. Marka u Zagrebu poklonila Maruša Pavla Neureutterova, a potom ga je Društvu umjetnosti darovao župnik Stjepan Boroša 1903. godine. Djelo je prvi put izloženo u Zagrebu na izložbi češkog umjetničkog društva Mánes u Umjetničkom paviljonu od svibnja do srpnja 1904. godine. Slijedi slika Mirka Račkoga koja je dopremljena iz Praga u rujnu 1904. godine, a slikar ju je darovao u zahvalu za financijsku potporu koju mu je Društvo dodijelilo za studij na likovnoj akademiji u Pragu. Društvo je platilo transport slike iz Praga i ona je izlagana na Jubilarnoj izložbi Društva umjetnosti u Umjetničkom paviljonu od travnja do konca svibnja 1905. godine. Meštrovićev »veliki reljef « dopremljen je u Zagreb u srpnju 1905. godine, također kao poklon umjetnika u zahvalu na financijskoj potpori, dok je Društvo platilo lijevanje u sadri bečkom ljevaču. Prvi put je pokazan u Zagrebu na izložbi Hrvatskog društva umjetnosti u Umjetničkom paviljonu u rujnu i listopadu 1906. godine.

Citirajući u cijelosti Izviješće tajnika gosp. Dra. A Schneidera s Godišnje skupštine Društva umjetnosti iz prosinca 1905. godine: »(...) Pitanje osnutka jedne nove moderne galerije na način mletačke, bečke i praške počešće se javljalo u radu našeg društva. Tako je najzad u proljeću ove godine naše društvo zaključilo, da po mogućnosti i prema svojim skromnim raspoloživim sredstvima doprinese svoj dio do osnutka ovakove moderne galerije. Kako je i ostvarenje tog pitanja u daljoj, ali nadamo se doglednoj budućnosti, tako se detalji nisu točnije ispitivali i pretresivali. Društvo je za ovu modernu galeriju odredilo već 3 umjetnine. Od ovih je jednu nabavilo svojim sredstvima. Meštrović je svoju veliku grupu 'Timor Dei', koja je proljetos u Beču veoma pohvalno primljena, poklonio društvu umjetnosti, a ovo mu je nadoknadilo samo materijalne izdatke; (isto tako i Račkovu veliku sliku 'Pred vratima smrti'), Bilekov relief Isus i Magdalena primilo je društvo na dar od pokojnoga 
župnika Stjepana Boroše. Tijem je učinjen prvi korak, a mi se pouzdano nadamo, da će nas u našem nastojanju pomoći i drugi ljubitelji umjetnosti i imućnici «, ${ }^{64}$ zaključujemo da te 1905. godine Moderna galerija još nije formalno utemeljena, ali su prikupljena tri djela za njezin budući fundus, nevezano uz održavanje Jubilarne izložbe. Geneza zbirke u kojoj su se našla dva djela hrvatskih $\mathrm{i}$ jedno češkog umjetnika, upućuje na nakanu sakupljanja djela sa širega europskog prostora, a ne isključivo nacionalnih. ${ }^{65}$ Djela stranih umjetnika tek će povremeno izlaziti iz depoa, a kako su pokazale izložbe
Strani slikari 19. stoljeća iz fundusa Moderne galerije, $2005 .{ }^{66}$ te Strani kipari i medaljeri iz fundusa Moderne galerije, 2015. godine, riječ je o znatnom i zanimljivom udjelu koji svjedoči o kulturno-povijesnoj usredotočenosti zagrebačke sredine na europsku modernu umjetnost u širem smislu i to u jeku njezina nastanka, čemu potvrdu nalazimo i u činjenici da su slika Mirka Račkoga i reljef Františeka Bíleka, te skulptura Ivana Meštrovića nastali u važnim srednjoeuropskim umjetničkim centrima Pragu odnosno Beču, s kojima je Zagreb početkom 20. stoljeća imao čvrste kulturne spone.*

\section{Bilješke}

* Na uvidu u muzejsku dokumentaciju i dobivanju podataka o umjetničkim djelima Mirka Račkoga, Ivana Meštrovića i Františeka Bíleka zahvaljujem Martini Munivrana (Muzej suvremene umjetnosti), Ladi Bošnjak Velagić (Moderna galerija), Vesni Mažuran Subotić, Tihani Boban i Filipu Turkoviću Krnjaku (Gliptoteka HAZU).

1

K. [ISO KRŠNJAVI], Hrvatski salon 1898., VI. Ekonomske prilike naše umjetnosti (Zaključni članak), u: Narodne novine, LXV, br. 11, 14. siječnja 1899., 1-2; Serijal članaka o izložbi Hrvatskog salona objavljenih u Narodnim novinama: I. Što je secesija?, LXIV, br. 295 (1898.), 1-2., II. Umjetnost i obćinstvo, LXV (1899.), br. 1, 1-2; III. Naši slikari, br. 2, 1-2; IV. Naši kipari, br. 5,1-2; V. Nuditet u umjetnosti. Publikacija izloženih slika, br. 10, 1-2; VI. Ekonomske prilike naše umjetnosti, br. 11, 1-2, Kršnjavi je objedinjeno pretiskao u knjizi Kritična razmatranja, U Zagrebu 1899. Nakladom knjižare Lavoslava Harmana (Kugli i Deutsch), navedeni citat na str. 27.

2

HR-HDA-1979, HDLU, kut. 11, dokument-račun: Slavnoj upravi Društva umjetnosti u Zagrebu - potvrda o kupovini od 10. siječnja 1899. U potpisu su tajnik Društva hrvatskih umjetnika R. Valdec i blagajnik R. Auer, a isplatu potpisuje Kršnjavi u ime Društva umjetnosti. Činjenica je da su neka od tih djela kasnije dospjela u fundus Moderne galerije (V. Bukovac, Japanka, O. Iveković, Predstraža na Kodrunu, B. Csikos, Pietà), a danas su u stalnom postavu. Kršnjavi će ih spomenuti i u svom Pogledu na razvoj hrvatske umjetnosti u moje doba. Iz mojih zapisaka, u: Hrvatsko kolo, 1905., 205-307., pretisak u: ISO KRŠNJAVI, Pogled na razvoj hrvatske umjetnosti u moje doba, u: Iso Kršnjavi, Zapisci. Iza kulisa hrvatske politike, (prir.) Ivan Krtalić, Zagreb, 1986. sv. I, 382-442, 430., cit.: »Društvo umjetnosti dokazalo je svoju potpunu objektivnost, pa je na izložbi svojih protivnika kupilo četrnaest slika. Među ovima bila je Csikoseva slika Pietà. Slika je vrlo lijepo zamišljena. Negotova i ona, ali s dobrim osjećajem risana. (...) Od Bukovca smo kupili malu sliku Japanka. Tri slike: od Bukovca, Csikosa i Ivekovića darovalo je Društvo umjetnosti Strossmayerovoj galeriji slika, a jedanaest je razdijelilo ždrebanjem među članove.«.

3

ISO KRŠNJAVI (bilj. 1, 1899.), 26-27.

4

HR-HDA-1979, HDLU, kut. 15, Koncept pravila za izložbe u Umjetničkom paviljonu (1901.), cit.: »10a. Eventualni višak poslovne godine upotrebljuje se za kupljenje izloženih umjetnina de se utemelji u paviljonu moderna galerija.»
5

Katalog izložbe Društva umjetnosti, 1902. (15. kolovoza - 31. listopada), 14, Kos Ivan, Karlsruhe, kat. br. 280. Nacrt za hrvatsku galeriju umjetnina; 281. Rasjek istoga; 282. Pročelje hrvatske galerije umjetnina. Ivan Kos rođen je 28. travnja 1871. u Zagrebu; upisan je u 1. razred graditeljskog odjela Kraljevske zemaljske muške obrtne škole u Zagrebu 1895., a završio ju je 1899. godine u generaciji s Aladarom Baranyjajem, Slavkom Benedikom i Dionisom Sunko. U vrijeme održavanja izložbe studirao je na Višoj tehničkoj školi u Karlsruheu. Radio je kao inženjer u građevinskom odsjeku Zemaljske vlade.

6

Kršnjavi [ISO KRŠNJAVI], Izložba Društva umjetnosti, u: Narodne novine, LXVIII, br. 232, 9. listopada 1902., 1-3, 2; Ovom je izložbom najavljeno spajanje »secesioniranog « Društva hrvatskih umjetnika i Društva umjetnosti. Na Odborskoj sjednici Društva umjetnosti održanoj 6. travnja 1902. kojoj su prisustvovali Robert Frangeš i Bela Csikos Sesia, Frangeš predlaže da se najesen održi izložba u Umjetničkom paviljonu i da se zajedno s izložbom aktivira fuzija dvaju društava. HR-HDA-1979, HDLU, kut. 2, Zapisnik Odborske sjednice.

7

U ovom se tekstu puni nazivi, Društvo za umjetnost i umjetni obrt do 1903. godine, a potom Hrvatsko društvo umjetnosti, skraćuju na uvriježenu izvornu varijantu Društvo umjetnosti, kako je to obrazložila Olga Maruševski u uvodnom tekstu knjige Društvo umjetnosti 1868.-1879.-1941. Iz zapisaka Hrvatskog društva likovnih umjetnika, DPUH, Zagreb, 2004., 11-15, 15. O povijesti Društva umjetnosti i njegovim mijenama vidjeti i: 150 godina Hrvatskog društva likovnih umjetnika. Umjetnost i institucija, (ur.) Irena Kraševac, Hrvatsko društvo likovnih umjetnika i Institut za povijest umjetnosti, Zagreb, 2018.

8

Izložba je svečano otvorena 24. travnja i trajala je do 31. svibnja 1905. godine.

9

Godišnje izvješće Društva umjetnosti za godinu 1905., Zagreb, Nakladom Društva umjetnosti. Tisak kr. zemaljske tiskare, 1906.; u tome: Izvješće tajnika gosp. dr. A. Schneidera, 16-19, navedeni cit. na str. 17-18.

10

Govor predsjednika Ise Kršnjavija na godišnjoj skupštini bio je fokusiran isključivo na probleme izgradnje Zagreba i ne dotiče se osnutka Moderne galerije. Osim u Godišnjem izvješću, govor je tiskan i u novinama, usp.: Dr. Kršnjavi, Agramer Stadtverschöne- 
rungs-Probleme, u: Agramer Zeitung, 23. prosinca 1905., 9, 11, 13.; Govor održan na glavnoj skupštini Društva umjetnosti 17. 12. 1905. o urbanističkim problemima Zagreba, u: Narodne novine, LXXI, br. 290, 1905., 1-4.

11

Usp. JELENA USKOKOVIĆ, Mirko Rački, Grafički zavod Hrvatske, Zagreb, 1979., 27., cit.: [Slika Mirka Račkog Pred vratima smrti] »bila je izložena na izložbi Društva umjetnosti u Zagrebu 1905, gdje je zajedno s Meštrovićevom skulpturom 'Timor Dei' otkupljena za Društvo umjetnosti. (Tim otkupom započinje skupljanje fundusa zagrebačke Moderne galerije.)«; JELENA USKOKOVIĆ, Prvih osamdeset godina Moderne galerije u Zagrebu, 97-125., u: Moderna galerija. Povijest palače, ustanove, obnove, (ur.) Igor Zidić, Moderna galerija, Zagreb, 2005. cit.: »(...) Godinom nastanka, stoga, smatramo i mi 1905. kad Društvo za fundus Moderne galerije nabavlja s jubilarne izložbe tri djela: skulpture Timor Dei Ivana Meštrovića, Isus i Magdalena Františeka Bileka te sliku Pred vratima smrti Mirka Račkoga." Tekst je pretisak s manjim dopunama autoričina članka Osamdeset godina Moderne galerije $\mathrm{u}$ Zagrebu, iz časopisa 15 dana, Zagreb, XXVIII/1985. br. 8, 22-31.; OLGA MARUŠEVSKI, Dva poglavlja u povijesti Društva umjetnosti. U povodu 100-te godišnjice Hrvatskog društva likovnih umjetnika, u: Bulletin JAZU, 1979., br. 2 (48), 13-45. Tekst je nastao kao izlaganje na skupu Sto godina Hrvatskog društva likovnih umjetnika koji je 23. veljače 1978. organizirala Jugoslavenska akademija znanosti i umjetnosti, a Maruševski je tom prigodom prvi put iznijela rezultate svojih istraživanja o historijatu Društva umjetnosti. Cit. na str. 40: »U proljeće 1905. godine Društvo skromnim sredstvima improvizira galeriju, u koju su ušla samo tri djela. To je Meštrovićeva grupa Timor dei u sadrenom odljevu, koju je on sam poklonio, zatim triptihon Račkoga Pred vratima smrti, slikan po narudžbi Društva i reljef u drvu Isus i Magdalena češkog kipara Františeka Bileka, poklon župnika crkve sv. Marka, Stjepana Boroše. To je začetak fundusa današnje Moderne galerije.« Kao godina utemeljenja Moderne galerije prihvaćena je 1905. premda za to nema čvrste osnove, jer se unutar Društva umjetnosti razgovaralo tek o mogućnosti njenog osnutka, dok je 1909. godina prvog postava u sklopu Muzeja za umjetnost i obrt otvorenog samo za zainteresirane pojedince. Hrvatsko društvo umjetnosti je prostorije za svoj rad i društvene sastanke imalo u prostoru Muzeja, dvjema prostorijama u prizemlju lijevo. Godine 1914. Galerija je nakratko otvorena za javnost, da bi zbog Prvoga svjetskog rata bila zatvorena i tek 1920. godine ponovno otvorena.

12

Usp. OLGA MARUŠEVSKI, Društvo umjetnosti 1868.-1879.1941., DPUH, Zagreb, 2004., 242. Autorica donosi popis izlagača i djela, a pritom kao izvor navodi katalog Jubilarne izložbe Društva umjetnosti. Naknadnom usporedbom ovog kataloga i kataloga izložbe Hrvatskoga društva umjetnosti iz 1906. ustanovljeno je da se navedeni popis podudara s tim katalogom. U Arhivu Maruševski u Institutu za povijest umjetnosti čuva se autoričina građa i rukopisi koji su joj poslužili u istraživanju i kod pisanja članaka i knjiga na temu Ise Kršnjavija i Društva umjetnosti, pri čemu i svežanj fotokopija navedenih kataloga, čije su naslovnice i sadržaj bili pomiješani. Zbog te pogreške podatak da je na Jubilarnoj izložbi 1905. "započelo i skupljanje radova za Modernu galeriju, a Meštrović poklonio sadru Timor Dei« ušao je kao krivi navod u literaturu. Katalozi izložaba Društva umjetnosti čuvaju se u Arhivu za likovne umjetnosti HAZU (dalje: ARLIKUM), a mogu se pretražiti i u digitalnom repozitoriju DiZbi.

13

Katalog jubilarne izložbe Društva umjetnosti, Umjetnički paviljon, Zagreb, 1905., str. 14: MEŠTROVIĆ IVAN, BEČ, 180. Studija za spomenik Luke Botića, sadra; 181. Gospodjica medicinarka, sadra; 182. Moja puca, sadra; 183. Skica za Vegin spomenik, sadra; 184. Majčina briga, sadra; 184. Punctum interrogativum, sadra; 186. Curica, sadra; 187. Dijete, sadra; 188. Mislilac, sadra; 189. Conte
Ugolino, sadra. Str. 15: RAČKI MIRKO, PRAG, 200. Na vratima smrti, uljena slika; 201. Studije za Danteovu »Božansku komediju«, crteži perom.

14

Iso Kršnjavi objavio je serijal od četiri članka naslovljenih Jubilarna izložba Društva umjetnosti (I-IV), u Narodnim novinama, LXXI, br. 101, 3. svibnja 1905, 1-2; 107, 10. svibnja 1905, 2-3; 116, 20. svibnja 1905., 1-2. i 124, 30. svibnja 1905., 1-2. Pretisak tekstova u: ISIDOR KRŠNJAVI, Listovi iz Slavonije / Članci, (prir.) Katica Čorkalo, Ogranak Matice hrvatske Vinkovci, HAZU Centar za znanstveni rad Vinkovci, 1995., 441-462.

15

ISO KRŠNJAVI (bilj. 2, 1986.), 382-442, 441.

16

Isto.

17

O Dušanu Plavšiću kao predsjedniku Društva umjetnosti od 1919. do 1927. vidjeti: IRENA KRAŠEVAC, »Plavšić smijenio Kršnjavija«. Hrvatsko društvo umjetnosti na prijelomnici 1918./1919., u: Zbornik IV. kongresa hrvatskih povjesničara umjetnosti, DPUH, Zagreb, 2019., 219-228.

18

Društvo umjetnosti u Zagrebu (izvještaj), u: Savremenik, god. XIV, 7/8 (1919.), 395-398., 397.

19

Popis djela može se rekonstruirati na temelju dokumenta MODERNA GALERIJA DRUŠTVA UMJETNOSTI (strojopis) koji se nalazi se u arhivskom fondu HR-HDA-757, Obitelj Plavšić.

20

ANTUN JIROUŠEK, Moderna galerija Društva umjetnosti, u: Obzor, 305 (1927.), 2-3.; Antun Jiroušek (Križevci, 1873.- Zagreb, 1948), povjesničar umjetnosti, ravnatelj Muzeja za umjetnost i obrt od 1925. do 1933. i Moderne galerije od 1933. do 1940.

21

(iš) [IVO ŠREPEL], Moderna galerija, u: Jutarnji list, 8004 (1934.), 13. svibnja 1934., 7-8., pretisak u: Ivo Šrepel. Dokumenti, vrijeme, sudbina. Biblioteka Povijest Moderne galerije, knj. 2, (ur.) Libuše Jirsak, Moderna galerija Zagreb, 2010., 82-84, 82. Svečano otvorenje Galerije održano je 16. svibnja 1934.; Ivo Šrepel (Zagreb, 1899. - nepoznato točno mjesto smrti, vjerojatno Lepoglava, 1945.), likovni kritičar, upravitelj Moderne galerije od 1940. do uhićenja 1944. godine.

\section{2}

IVO ŠREPEL, Moderna galerija u Zagrebu, u: Hrvatska revija, 8 (1938.), 440-442., pretisak u: IVO ŠREPEL Dokumenti, vrijeme, sudbina. Biblioteka Povijest Moderne galerije, knj. 2, (ur.) Libuše Jirsak, Moderna galerija Zagreb, 2010., 167-170, 167. Zbirka je tada obuhvaćala preko 250 radova od 100 domaćih i stranih umjetnika.

23

Vidjeti bilješke 11 i 12.

24

JELENA USKOKOVIĆ (bilj. 11, 1979.), 15.

25

Pisma Mirka Račkoga Izidoru Kršnjavom čuvaju se u arhivskom fondu HR-HDA-804, Iso Kršnjavi, kut. 14, dok su pisma Mirka Račkoga u vrijeme rada Jelene Uskoković na monografiji još bila u njegovu vlasništvu. Uz stipendiju Vlade i potpore Društva umjetnosti, Kršnjavi je i vlastitim sredstvima pomagao umjetnike, u ovom slučaju Račkoga. Crtež Pred vratima smrti, 1904., tuš, pero, $165 \times 410$ mm, sign. nema, bio je vlasništu Bogdana Kršnjavija; dok je uljena skica Pred vratima smrti (studija), 1904., ulje, kar- 
ton, 50,5 ×99,5 cm, sign.d.d.k.: Mirač Prag 904, danas u Zbirci Benko Horvat, Muzej suvremene umjetnosti, Zagreb (na trajnoj posudbi u Hrvatskom saboru). Provenijencija dolaska u zbirku Benka Horvata je iz zbirke Ise Kršnjavoga. Uočena je i pogreška u monografiji Mirka Račkoga u kojoj je na str. 82 reproducirano djelo Pred vratima smrti, 1904. pod kat. br. 11 je neodgovarajuće, jer je reproducirana skica/studija, a katalog navodi sliku na str. 245. Usp.: JELENA USKOKOVIĆ (bilj. 11), 82, 134, 245.

\section{6}

Pismo Kršnjavoga Račkomu od 19. IV 1904. u: JELENA USKOKOVIĆ (bilj. 11, 1979.), 16.

\section{7}

ARLIKUM, Društvo umjetnosti, omotnica 1, Knjiga računa Društva umjetnosti (Cassa), 1904. Datum: 23/IX »Dovoz slike koju šalje Rački učenik akademije u Pragu, 8.54 [Kruna] «; 25/X. »Rački Mirko, slušatelj na akademiji tvornih umjetnosti u Pragu VII 100«; 22/IV. »Mirko Rački slušatelj akademije tvornih umjetnosti u Pragu VII dobiva od društvene potpore 30.«

28

ARLIKUM (bilj. 27), Dovoz slike M. Račkog od 23. rujna 1904.

29

JELENA USKOKOVIĆ (bilj. 11, 1979.), 27.

30

Katalog jubilarne izložbe Društva umjetnosti, 1905., str. 15: RAČKI MIRKO PRAG. 200. Na vratima smrti, uljena slika; 201. Studije za Danteovu »Božansku komediju«, crteži perom; podatak iz inventarne knjige Moderne galerije: Mirko Rački, Pred vratima smrti, 1904., ulje na platnu, $89 \times 176 \mathrm{~cm}$, sign. d.d.k: »Mirač, Prag, 1904.« Moderna galerija, Zagreb, MG-937.

31

Kršnjavi zimi 1903./1904. boravi u Beču gdje posjećuje Klimtovu izložbu o kojoj će objaviti kritički osvrt u Narodnim novinama. Vidjeti: XVIII. Ausstellung der Vereinigung bildender Künstler Österreichs - Secession. Kollektiv Ausstellung Gustav Klimt, November - Dezember 1903. katalog izložbe; Dr. KRŠNJAVI, Klimtova izložba u Beču, u: Narodne novine, god. LXX, br. 24, 30. siječnja 1904., 1-2; Premda se Kršnjavi izrazito negativno osvrće na Klimtova djela, ta je izložba naročito utjecala na Ivana Meštrovića u čijoj se ostavštini u Atelijeru Meštrović u Zagrebu nalazi i katalog, a Klimtova djela, poglavito tada prvi put izložene sve tri Fakultetske slike (Filozofija, Medicina i Justicija), inspirirat će ga za neke od njegovih najznačajnijih radova bečkog razdoblja.

32

HR-HDA-1979, HDLU, kut. 2, Zapisnik Odborske sjednice održane 14. lipnja 1904. u knjižnici Obrtne škole. Prisutni Kršnjavi, Bollé, Bojničić, Brunšmid, Crnčić, Čikoš, Deželić, Granitz, Kovačević, Miletić i Šilović. Vidjeti i: ARLIKUM, fond Društvo umjetnosti. Knjiga blagajne za 1904., br. 118. (25. VI.) Kiparu Meštroviću glasom zajedničkog zaključka podijeljena potpora 200 kruna.

33

HR-HDA-1979, HDLU, kut. 2, omotnica: Skupština 1917. Rukopis Ise Kršnjavija o pomaganju umjetnika.

34

XXIII. Ausstellung der Vereinigung Österreichischer Künstler Secession, 24. 3.-14. 6. 1905. IVAN MEŠTROVIĆ, Kat. Nr. 67. Timor Dei (Jubilarna izložba Društva umjetnosti trajala je od 24. 4. do 31. 5. 1905.)

35

U Hrvatskom državnom arhivu, fondu HR-HDA-804, Izidor Kršnjavi, kut. 3, sačuvana su pisama i dopisnice koje je Meštrović slao Kršnjaviju iz Beča, Pariza i Splita u razdoblju od 1904. do 1910. godine. Rukopisnu građu transkribirala je i obradila Ljiljana Čerina, muzejska savjetnica Muzeja Ivana Meštrovića, Atelijera Meštrović u Zagrebu u suradnji s autoricom ovog članka. Fragmenti pisma Ivana Meštrovića Isi Kršnjaviju i preslika dvaju pisama Kršnjavija Meštroviću objavljeni su u knjizi: DUŠKO KEČKEMET, Život Ivana Meštrovića (1883.-1962.-2002.), 1. svezak (1883.-1932.), Školska knjiga, Zagreb, 2009., u poglavlju »Izidor Kršnjavi«, 105-122, 111-112. Transkripti pojedinih pisama ne odgovaraju u cijelosti originalima, te se upućuje na korištenje izvorne građe. 36 HR-HDA-1979, HDLU, kut. 6, Pismo Ivana Meštrovića od 23. kolovoza 1905. kojim javlja da uplate Lazaru Benettiju ljevaču u Beču »stvari za izložbu 1905«.

37

U pismima se također spominje i prijenos skulpture u trajni materijal, te Meštrović u pismu od 20. svibnja 1905. predlaže tamni kamen. Odljev u bronci realiziran je tek 1987. u povodu izlaganja u Berlinu, Zürichu i Beču, vidjeti: Ivan Meštrović. Skulpturen, katalog izložbe, Nationalgalerie, Staatliche Museen Preußischer Kulturbesitz, Berlin, 1987. U katalogu je reproducirano djelo u sadri, »Kat. Nr. 4, Timor Dei, 1904, Gips, $200 \times 145 \times 120 \mathrm{~cm}$, Bez. rechts unten: Meštrović (in kyrillischen Schrift), Moderna galerija, Zagreb, Inv. Nr. 732, Gestiftet von der Gesellschaft für Kunst und Literatur, Zagreb« (sic!). Nakon odlijevanja u Ljevaonici umjetnina, originalna sadra je jako oštećena pri čemu je baza skulpture razlomljena na više dijelova. Tako oštećena sadra čuva se u depou Gliptoteke HAZU, dok je brončani odljev u stalnom postavu hrvatske skulpture 19. i 20. stoljeća u istoj ustanovi. Premda je u navedenom katalogu ova skulptura u sadri zavedena kao vlasništvo Moderne galerije, Inv. br. 732, istraživanje je pokazalo da se u današnjoj inventarnoj bazi podataka fundusa Moderne galerije Timor Dei uopće ne nalazi. Prema inventarnoj knjizi Gliptoteke iz 1950. godine, zavedena je kao vlasništvo autora. Oštećena sadrena skulptura vodi se pod inv. br. MZP-732, dok je brončani odljev iz 1987., inv. br. MZ-675 vlasništvo Gliptoteke HAZU. Dozvolu za lijevanje potpisala je uime nasljednika Marija Meštrović, 8. siječnja 1987. godine. Izložba u Berlinu otvorena je 29. siječnja 1987., što bi bio vrlo kratak rok za lijevanje i finalno cizeliranje skulpture, koja je u katalogu reproducirana u sadrenoj varijanti, snimljenoj netom prije lijevanja i oštećenja. Kada je došlo do izvlaštenja sadrene skulpture koja se smatra jednim od prva tri djela za fundus Moderne galerije, zasada nije bilo moguće utvrditi. 38

HR-HDA-1979, HDLU, kut. 6.: Potvrda Ivana Meštrovića Hrvatskom društvu umjetnosti u Zagrebu 28. srpnja 1905. da je primio 270 kruna za Timor Dei i dodatnih 300 kruna. Kršnjavijeva opaska na potvrdi: Isplaćeno 1140 Meštroviću, Kršnjavi.

39

(-), Naš umjetnički podmladak, u: Narodne novine, LXXI, br. 172 , 29. srpnja 1905., 2. Autor ove kratke vijesti iz umjetničkog života Zagreba je nepotpisan, ali pretpostavljamo da je riječ o Isi Kršnjaviju koji je izvještavao o aktivnostima Društva umjetnosti za Narodne novine, a na taj način ujedno popularizirao umjetnost i predstavljao mlade umjetnike.

40

Izložba Hrvatskog društva umjetnosti, Umjetnički paviljon, 1. 9.-15. 10. 1906. katalog izložbe navodi MEŠTROVIĆ IVAN, BEČ, kat. br. 121. Zidanje Skadra, reljef, sadra; 122. Umjetnik naroda moga, reljef, sadra i 123. Timor Dei, sadra.

41

Vidjeti: IRENA KRAŠEVAC, Ivan Meštrović i Secesija. Beč München - Prag 1900-1910., Zagreb, 2002., Poglavlje: »Simbolizam u secesiji«, 75-67.

42

Iso Kršnjavi, Izložba Hrvatskog društva umjetnosti, u: Hrvatska smotra, I., Zagreb, 1906., 77-83. Pretisak (bilj. 14, 1995.), 463-472, 464-465. 
43

HR-HDA-804, Izidor Kršnjavi, kut. 12, omotnica Štampa i razni zapisi o Ivanu Meštroviću, rukopis Kršnjavijeva odgovora na tekst Svetozara Rittiga. Meštrovićeva umjetnost, u: Katolički list, 44, 4. studenog 1920., 337-339.

44

Usp. LJILJANA ČERINA, Ivan Meštrović, likovi i prizori Danteova Pakla: ilustracije i interpretacije, katalog izložbe, Gliptoteka HAZU i Fundacija Ivana Meštrovića, Zagreb, 2004.

45

IRENA KRAŠEVAC, PETRA ŠLOSEL, Networking Central European Artists' Association via Exhibitions. The Slovenian Art Association, Czech Mánes and Polish Sztuka in Zagreb in the Early $20^{\text {th }}$ Century, u: Modern and Contemporary Artists Networks. An Inquiry into Digital History of Art and Architecture, (ed.) Ljiljana Kolešnik, Sanja Horvatinčić, Institut za povijest umjetnosti, Zagreb, 2018., 16-36 [Mrežno izdanje].

46

Izložba češkog umjetničkog društva »Manes«, katalog izložbe, 1904. BILEK FR, kat. br. 5. Dobri pastir, bronca; 6. Alegorija našeg doba, bronca; 7. Magdalena; 8. Deset dekorativnih posuda iz paljene gline; 9. Krist; 10. Nadgrobni relief, paljena glina; 11. Rastanak, plaketa; 12. Sastanak, plaketa; 13. Nadgrobni relief.

47

ISO KRŠNJAVI, serijal članaka o izložbi češkog umjetničkog društva Mánes objavljen je u Narodnim novinama: Izložba čeških umjetnika Društva »Manes « u Zagrebu, LXX; br. 110, 14. svibnja 1904., 1-2; Kipari u izložbi čeških umjetnika, 112, 17. svibnja 1904., 1-2; Slikari u izložbi čeških umjetnika, 116., 21. svibnja 1904., 1-2; Češki slikar Kupka na izložbi, 121, 28. svibnja 1904., 1-2; Izložba čeških umjetnika. (Još jedanput Kupka - Švabinski -Stretti), 126, 4. lipnja 1904., 1-2; Soba najljepših slikâ u izložbi, 138, 18. lipnja 1904., 1-2 i Zaključna riječ o izložbi »Manesa«, 146, 28. lipnja 1904., 1-2. Pretisak tekstova (bilj. 14, 1995.), 413-440.

48

ISO KRŠNJAVI (bilj. 47), Izložba čeških umjetnika društva »Manes«.

49

ISO KRŠNJAVI (bilj. 47), Kipari u izložbi čeških umjetnika.

50

Katalog izložbe Društva Manes, II. prošireno izdanje. Zbirka kataloga u Arhivu za likovne umjetnosti HAZU.

51

Temu je autorica prvi put izložila na simpoziju Skulptura $u \mathrm{Mu}$ zeju, Klanjec, 24.-26. listopada 2018., a izlaganje je objavljeno u zborniku radova tog skupa; IRENA KRAŠEVAC, S izložbe u depo. Sudbina reljefa Isus i Magdalena Františeka Bíleka, u: Anali Galerije Antuna Augustinčića, God. XXXVIII-XXXIX (2018.-2019.), Klanjec, 2019., 113-123. (prethodno priopćenje). U ovom se članku donose nove spoznaje o djelu i njegovom dolasku $\mathrm{u}$ fundus Moderne galerije.

52

HR-HDA-1979, HDLU, kut. 2, Zapisnik odborske sjednice održane 28. listopada 1903. u čitaonici Obrtnog muzeja, cit.: »Pod predsjedništvom presvjetlog gosp. prof. dra I. Kršnjavog. Prisutni članovi odbora: Bojničić, Bollé, Bothe, Brunšmid, Crnčić, Deželić, Frangeš i Schneider. (...) Gdja Neureuther poklonila je župnoj crkvi sv. Marka relief F. Bileka 'Magdalena'. Zupnik g.dr. Boroša poklonio je taj relief društvu umjetnosti. Relief želi se deponirati. Odbor ga prima i izreći će mu zahvalnost. «Stjepan Boroša (Stubica, 1. 8. 1856. - Rim, 31. 1. 1905.), politički pisac, doktor teologije, vjeroučitelj u Križevcima i Varaždinu. Kapelan, potom župnik crkve sv. Marka u Zagrebu (1890.-1903.). Dobrotvor siromašnih đaka i studenata. Izvor: Leksikon Križevčana. Prilog poznavanju povijesti Križevaca i križevačkog kraja, (prir.) Rade Milosavljević, Križevci, 1988., 21; Hrvatski biografski leksikon, 2, Bj - C, JLZ »Miroslav Krleža«, Zagreb, 1989., 169-170.

53

Neogotička obnova crkve sv. Marka započela je 1875. godine prema projektu restauracije Friedricha Schmidta, koju nastavlja Herman Bollé. Obnova je završena posvetom crkve 29. listopada 1882. V.: DRAGAN DAMJANOVIĆ, Schmidt-Bolléova obnova crkve u drugoj polovici 19. stoljeća, u: Crkva sv. Marka u Zagrebu. Arhitektura, povijest, obnova, (ur.) Petar Puhmajer, Hrvatski restauratorski zavod, Zagreb, 2013., 63-96.

54

FILIP DAVIDOVIĆ MARUŠIĆ, Fr. Bílek (studija), u: Život, I, MCM, sv. IV, 133-137., 136. Uz tekst su objavljene dvije reprodukcije Bílekovih djela, Kalvarija i Krist. Filip Davidović Marušić (Omiš, 1874.- Trbounje, 1944.), liječnik, prirodoslovac, književnik. Član staroga plemstva Poljičke republike. Godine 1903. dolazi u Drniš za rudarskog liječnika u Siverić i općinskog liječnika Drniša. Studirao je medicinu u Pragu, gdje dolazi u kontakt s obitelji Neureutter, Theodorom (Bohdanom), liječnikom i profesorom na medicinskom fakultetu i njegovim bratom Karlom, vojnim intendantom, suprugom Maruše Pavle Neureutterové. Djelo spomenuto u tekstu, Podobenstvi velkého západu Čech, 1898., drveni reljef, danas je u zbirci Nacionalne galerije u Pragu, Inv. br. P-1441.

55

DAMIR AGIČIĆ, Hrvatsko-češki odnosi na prijelazu 19. u 20. stoljeće, Zagreb, Ibis grafika, 2000., 141. Za podatke o Maruši Pavli Neureutterovoj zahvaljujem Marijanu Lipovcu, predsjedniku Hrvatsko-češkog društva u Zagrebu.

56

ALEŠ FILIP - ROMAN MUSIL, Discussion of František Bílek's merits in Catholic Modernism, u: František Bílek (1872-1941), monografska publikacija uz izložbu u Gradskoj galeriji Praga (Galeríe hlavniho města Prahy), 10. studenoga 2000. - 4. veljače 2001., 66-75, 66. U sklopu Gradske galerije Praga nalazi se Bílekova vila i atelijer na Hradčanima.

57

The Gardener of Our Lady, 1897, relief, black-coloured plaster, City Gallery Prague, P-1409, Reproducirano u monografskoj publikaciji (bilj. 57) na str. 36.

58

Karakteristična slova koja će rezbariti u okviru reljefa, pojavljuju se i u Bílekovim litografijama u časopisu Meditace, u kojem će objavljivati pisci okupljeni u krugu Katoličkih modernista (1895.-1907.).

59

Transkript i prijevod natpisa na okviru prvi put objavila je Đurđa Petravić u katalogu izložbe Strani kipari i medaljeri iz fundusa Moderne galerije, Studio Moderne galerije »Josip Račić«, katalog izložbe, Zagreb, 18. prosinca 2014. - 4. siječnja 2015., 12. Prijevod češkog izvornika glasi: »Što tražiš ovdje? Koga tražiš? Magdalena plačući, gledaše za Gospodinom kao za suncem na zalasku, - kao čovjek, u tuzi nad prolaznošću svojom; što on - blaženstvo vječno - je vazda uz nas s blagom otajstvenom Riječju« (dalje nečitko). Transkripciju teksta napravila je Maja Burger, a prijevod Maja Burger i Đurđa Petravić, uz pomoć engleskog prijevoda češkog transkripta. Autorica donosi i ikonološku interpretaciju Bílekova reljefa temeljenu na opisu iz Ivanova evanđelja. Neutemeljeno pak ponavlja podatak o nabavi, da je »Reljef s izložbe praškog umjetničkog udruženja 'Manes', održane u Zagrebu 1904., kupio župnik crkve sv. Marka Stjepan Boroša i 1905. ga darovao Društvu umjetnosti za Modernu galeriju« te kao izvor literature navodi (očito neprovjereni!) katalog Jubilarne izložbe Društva 
umjetnosti, Zagreb, 1905. Kako je djelo već 1903. bilo u Zagrebu, a Stjepan Boroša te godine prestaje biti župnikom župe sv. Marka te je iste godine i preminuo, predlaže se i pomicanje datacije nastanka na 1901./1902.

60

ANTON JIROUŠEK (bilj. 19), 2-3.

61

IVO ŠREPEL (bilj. 21, 2010.), 167-170, 167.

62

Reljef je predan na čuvanje u depo Gliptoteke JAZU slijedom Ugovora 65, 1.6.1954., br. 114.

63

U dokumentu vezanom uz posudbu za izložbu u Pragu, Zapisniku posudbenog ugovora MG, 23.08.2000., evidentirano je da je »izrezbarena baza reljefa jako crvotočna, do oštećenja rezbarije i pomaknuta iz ležišta«.

64

Godišnje izvješće (bilj. 9), 17-18.

65

U popisu 69 djela u vlasništvu Hrvatskog društva umjetnosti koja su evidentirana kod primopredaje 1918./1919. (bilj. 18) nalazimo imena stranih umjetnika: Brangwyn, Bush, Czajkowski, Delneri, Hartley, Klinger, Kleman, Lussi, W.d. Loo, Molnar Pentelei, Mezel Hoenemann, Pennell, Schmutzer, Saliger, Trapp, Vondrouš, Trainer, F. Carter, Giles, Muha, Orlič.

66

Strani slikari 19. stoljeća iz fundusa Moderne galerije, katalog izložbe, Moderna galerija, Zagreb, 28. prosinca 2004. - 30. siječnja 2005. Autorica izložbe i teksta u katalogu je Dajana Vlaisavljević.

\section{Summary}

\section{Irena Kraševac}

\section{The First Three Artworks in the Holdings of the Modern Gallery of the Art Society in Zagreb}

\begin{abstract}
The article reconstructs the founding of the Modern Gallery in Zagreb and the creation of its holdings, reviewing the data on the first three works acquired for the collection: the painting At the Gate of Death by Mirko Rački, the sculpture Timor Dei by Ivan Meštrović, and the relief Jesus and Mary Magdalene by František Bílek. Based on the archival documents and the exhibition catalogues of the Croatian Art Society, the author proposes a more accurate chronology and the circumstances around their acquisition.
\end{abstract}

It has been established that the first artwork received by the Art Society for the future collection of Modern Gallery in the early $20^{\text {th }}$ century was the wooden relief Jesus and Mary Magdalene by the Czech sculptor František Bílek, donated by Maruša Pavla Neureutterova from Prague to the parish church of St Mark in Zagreb and subsequently, in 1903, by the parish priest Stjepan Boroša to the Art Society. The work was first exhibited in Zagreb at the Art Pavilion, as part of the exhibition of the Czech Art Society Mánes from May to July 1904. Although part of the Modern Gallery holdings since its foundation, this artwork is rarely exhibited and is stored in the Glyptotheque of Croatian Academy of Sciences and Arts. The second artwork acquired for the Modern Gallery's collection was the painting At the Gate of Death by Mirko Rački, which was also shipped to Zagreb from Prague in September 1904, as the painter donated it to the Art Society as a sign of gratitude for the financial support granted for his studies at the Academy of Fine Arts in Prague. The Society paid for the transport of the painting from Prague and it was exhibited at the Jubilee Exhibition of the Art Society at the Art Pavilion from April to the end of May 1905. The painting is today part of the permanent exhibition of the Modern Gallery. The "great relief" Timor Dei by Ivan Meštrović was likewise brought to Zagreb as a gift presented by the artist in gratitude for the financial support granted for his studies at the Academy of Fine Arts in Vienna, and the Art Society paid for its casting in plaster at a Viennese foundry. It was first shown at the Spring Exhibition of the Viennese Secession in 1905, and in Zagreb at the exhibition of the Croatian Art Society in the Art Pavilion in September and October 1906. The plaster original was destroyed when the relief was cast in bronze in 1986 and is stored in the depot of the Glyptotheque HAZU, while the newer bronze cast is part of the collection of $19^{\text {th }}$ - and $20^{\text {th }}$-century Croatian sculpture in the same institution.

Although it is commonly held that the Modern Gallery in Zagreb was founded in 1905, we have concluded that the gallery was not formally established that year. However, three works were acquired for its future holdings regardless of the Jubilee Exhibition of the Croatian Art Society. The genesis of the collection, which by then featured two works by Croatian artists and one by a Czech, indicates an intention of collecting works from the wider European area, not exclusively national ones. Works by foreign artists would, however, only occasionally come to leave the depot, although they are a significant and interesting segment of the collection and witness to the cultural and historical focus of Zagreb on European modern art in a broader sense, moreover at its pinnacle, which is confirmed by the fact that the symbolist artworks, the painting by Mirko Rački, the relief by František Bílek, and the sculpture by Ivan Meštrović, were created in important Central European art centres - Prague and Vienna - with which Zagreb maintained active cultural contacts in the early $20^{\text {th }}$ century.

Keywords: Croatian Art Society, Modern Gallery, Zagreb, exhibitions, Iso Kršnjavi, Mirko Rački, Ivan Meštrović, František Bílek 


\section{Izvori ilustracija i autori fotografija / Sources of illustrations and photo Credits}

\begin{abstract}
Višnja Bralić
The Cult of Saint Euphemia, the Patron Saint of Rovinj, and the Venetian Politics of Co-creating Local Identities in Istrian Communities in the $15^{\text {th }}$ Century / Kult sv. Eufemije, zaštitnice Rovinja $i$ venecijanska politika sukreiranja lokalnih identiteta u istarskim zajednicama 15. stoljeća
\end{abstract}

1: (c) Museo Correr, Venezia (Giuseppe Rosaccio, Viaggio da Venezia a Costantinopoli, per mare e per Terra, \& insieme quello di Terra Santa, Venetia: Giacomo Franco, 1598, fol. 7v)

2-10: Ljubo Gamulin

\section{Anna Boreczky}

Historiography and Propaganda in the Royal Court of King Matthias: Hungarian Book Culture at the End of the Middle Ages and Beyond / Historiografija i propaganda na dvoru kralja Matije Korvina. Mađarska kultura knjige krajem srednjega vijeka i dalje

1-11, 14, 16-18: @ National Széchényi Library, Budapest (Országos Széchényi Könyvtár)

12, 13: ( ) Heidelberg University Library (Universitätsbibliothek Heidelberg)

15: From Wikimedia Commons, the free media repository

\section{Ivan Gerát}

Saint George Between Media and Functions / Sv. Juraj izmedu medija i funkija

1: Image courtesy National Gallery of Art, Washington DC

2: https://www.metmuseum.org/art/collection/, Public Domain

3: https://www.metmuseum.org/art/collection/, Public Domain

4, 5: Ivan Gerát

6: Archive of the Institute of Art History of the Slovak Academy of Sciences

\section{Ivan Ferenčak}

The Illustrations in the Glagolitic Books Printed by Bishop Šimun Kožičić Benja in Rijeka (1530-1531) / Ilustracije u glagoljskim knjigama biskupa Šimuna Kožičića Benje tiskanim u Rijeci (1530.-1531.)

1: Tamara Runjak, Rijetkosti u Knjižnici Hrvatske akademije znanosti i umjetnosti: katalog inkunabula i knjiga 16. stoljeća, Zagreb, 2011.

2, 7-10: Zagreb, Knjižnica Hrvatske akademije znanosti i umjetnosti, R-600, snimio Ivan Ferenčak 2019.

3: Ivan Ferenčak, 2019.

4: Biblioteca nazionale Marciana, Venezia, BM - Rari Ven. 579 (su concessione del Ministero per i Beni e le Attività Culturali - Biblioteca Nazionale Marciana. Divieto di riproduzione).

5: Biblioteca nazionale centrale di Firenze, Firenze, MAGL.2.1.109 (su concessione del Ministero dei beni e delle attività culturali. Biblioteca Nazionale Centrale di Firenze. Divieto di riproduzione)
6: Bibliothèque nationale de France, Paris, département Musique, RES-1527.

11: Nacionalna i sveučilišna knjižnica, Zagreb, RIIA- $8^{\circ}-8$.

12: Nacionalna i sveučilišna knjižnica, Zagreb, RIIA-16º-5.

\section{Milan Pelc}

Panegyric Emblem Books, Jesuits and the Habsburg Emperors: Some Examples Related to $17^{\text {th }}$-Century Croatia / Panegirički amblemi $i$ habsburški carevi - primjeri iz 17. stoljeća povezani s hrvatskom kulturnom sredinom

1: ๔ Hrvatski povijesni muzej, Zagreb / Croatian History Museum 2: ( University Library, Budapest / Egyetemi Könyvtár, Kézirattár 3-20: ๑ Austrian National Library, Vienna / Österreichische Nationalbibliothek

\section{Polona Vidmar}

Coesari in mis omni hora fidelis servivi: The Portraits of Sigismund Herberstein and Walter Leslie in Diplomatic Robes / Cæsari in mis omni hora fidelis servivi: Portreti Žigmunda Herbersteina $i$ Waltera Leslieja u diplomatskim odorama

1-2, 4, 6: Knjižnica Ivana Potrča Ptuj / Ivan Potrč Library Ptuj 3: Hollstein's German Engravings, Etchings and Woodcuts 1400-1700, vol. XIII A, 1984

5, 10, 13: Google Books

7-9, 11-12: Polona Vidmar

\section{Nóra G. Etényi}

Broadsheets with Engravings in a Manuscript Chronicle from Ulm: Visual Representations of the Hungarian Kingdom on German Political Leaflets during the War of Reconquest (1683-1699) / Grafički plakati u rukopisnoj kronici iz Ulma: Vizualna reprezentacija Ugarskog Kraljevstva na njemačkim političkim letcima tijekom Velikog turskog rata (1683.-1699.)

1, 4: (C) Austrian National Library Portrait Collection, Vienna / Österreichische Nationalbibliothek Porträtsammlung

2, 3, 6: @ Hungarian National Museum, Budapest / Magyar Nemzeti Múzeum

5, 7: @ National Széchényi Library, Budapest, Apponyi Sammlung / Országos Széchényi Könyvtár, Apponyi Metszet

\section{Werner Telesko}

Graphic prints of the Josephine period (1765/1790) and the propaganda of 'Religious Tolerance' / Grafički listovi Jozefinskog razdoblja (1765./1790.) i propaganda "Vjerske tolerancije"

1: ( ) Austrian National Library, Vienna

2: () Austrian National Library, Vienna

3: ㄷ Vienna Museum 
4: (C) Vienna Museum

5: (C) Vienna Museum

6: C Vienna Museum

\section{Martina Frank}

Representing the Republic in Seventeenth-Century Venice / Predstavljanje Republike u Veneciji 17. stoljeća

1, 3, 4, 5, 12: @ Austrian National Library, Vienna / Österreichische Nationalbibliothek

2, 15: Martina Frank

6: () University Library of Padua / Biblioteca universitaria di Padova

7: @ McNay Art Museum

8: Cat Bauer (https://venetiancat.blogspot.com/2016/11/thanksgiving-in-venice-celebrates-black.html)

9, 10: https://www.lamoneta.it/topic/157941-medaglia-nicol\% C3\%B2-contarini/

11: ๑ José Luiz Bernardes Ribeiro / CC BY-SA 4.0

13: Internet culturale

14: () Marciana National Library / Biblioteca Nazionale Marciana, Venezia

16: ( ) Museo Civico del Castello di San Giusto, Trieste

\section{Bálint Ugry - Maja Žvorc}

The Čakovec Stone Bust Collection: New Identifications, Possible Dating and the Identity of its Commissioner / Zbirka kamenih bisti u Čakovcu: Nove identifikacije, moguće datacije i naručitelj

1, 4, 6, 8, 10: Jovan Kliska

2: ๑ Austrian National Library (Österreichische Nationalbibliothek), Vienna

13, 15: ( ) Museum of Međimurje (Muzej Međimurja), Čakovec

3, 5, 7, 9, 11, 14, 16: Corpus Juris Hungarici, Tyrnaviae, 1751.

12: ( National Széchényi Library (Országos Széchényi Könyvtár), Budapest

17, 18: @ National Archives of Hungary (Magyar Nemzeti Levéltár), Budapest

19: Bálint Ugry

\section{Damir Tulić}

Glory Crowned in Marble: Self-promotion of Individuals and Families in Seventeenth- and Eighteenth-Century Monuments in Istria and Dalmatia / Slava okrunjena mramorom: Samopromocija osoba $i$ obitelji na spomenicima 17. i 18. stoljeća u Istri i Dalmaciji

1, 2, 3, 4, 5, 6, 7, 8, 9, 10, 11, 12, 13, 15, 16, 17: Damir Tulić

14: Samo Štefanac

\section{Jasminka Najcer Sabljak}

Portraits of Habsburg Rulers in the Aristocratic Collections of Eastern Croatia / Portreti vladara obitelji Habsburg u plemićkim zbirkama istočne Hrvatske

\author{
1, 2: ( $)$ Galerija Matice srpske, Novi Sad \\ 3: Francisca Clary-Aldringen \\ 4: Davor Šarić
}

\section{Danko Zelić}

Projekt Fausta Vrančića za opsadu Ostendea iz 1603. godine / Faust Vrančićs Design for the Siege of Ostend from the Year 1603

1: Matthias Dögen, Architectura militaris moderna (...), Amstelodami, 1647., 354-355.
2-4: ( ) Rijksarchief in België / Archives de l'État en Belgique, Algemeen Rijksarchief / Archives générales du Royaume, Fond Duitse Staatssecretarie / Secrétairerie d'État Allemande, 413, p. 309

5: Pompeo Giustiniano, Delle guerre di Fiandra libri 6. Di Pompeo Giustiniano del Consiglio di guerra di S. M. C. (...) Posti in luce da Gioseppe Gamurini (...) con le figure delle cose più notabili, In Anversa, 1609., 84-85

\section{Radoslav Tomić}

Generalni providur Leonardo Foscolo i umjetnost u Dalmaciji / Provveditore generale Leonardo Foscolo and Art in Dalmatia

1-30: Fotografije iz arhive autora

4: Presnimak iz: Alfons Pavich pl. Pfauenthal, Prinosi povijesti Poljica, Sarajevo, 1903., 79.

\section{Petar Puhmajer}

Dvorac Cernik - kontinuitet i mijene predturskog nasljeđa u barokno doba / The Cernik Castle - Continuity and Change in the Pre-Ottoman Heritage during the Baroque Era

1, 2, 9: Paolo Mofardin, Fototeka IPU

3 a, b; 6 a , b c c, d: arhitektonski snimak Sanja Štok i Barbara Kulmer, grafička obrada Marin Čalušić

4, 7, 10, 11: Petar Puhmajer

5: ๑ Generallandesarchiv, Karlsruhe

\section{Bojan Goja}

Kuća Cattinelli 1772. godine: prilog poznavanju stambene arhitekture u Zadru u 18. stoljeću /

The Cattinelli House in 1772: A Contribution to Our Knowledge of Housing Architecture in $18^{\text {th }}$-Century Zadar

1, 2: Bojan Goja

3, 4: Branko Maroević, dipl. ing. arh., izrada nacrta

\section{Iva Pasini Tržec}

Slike starih majstora iz zbirke Ervina i Branke Weiss u Strossmayerovoj galeriji u Zagrebu / Paintings of Old Masters from the Collection of Ervin and Branka Weiss in the Strossmayer Gallery in Zagreb

1, 3, 6: Arhiv Strossmayerove galerije HAZU, dokumentacija Weiss 2: MAK - Museum of Applied Arts (Museum für angewandte Kunst), Vienna

4: RKD - Netherlands Institute for Art History (Rijksbureau voor Kunsthistorische Documentatie), Den Haag

5: Palais Liechtenstein, Vienna

6: ( ) Strossmayerova galerija starih majstora HAZU

7: BDA - Bundesdenkmalamt Archiv (Federal Monuments Authority Austria Archive), Vienna

\section{Irena Kraševac}

Prva tri djela u fundusu Moderne galerije Društva umjetnosti / The First Three Artworks in the Holdings of the Modern Gallery of the Art Society in Zagreb

1, 4: Goran Vranić, Moderna galerija, Zagreb

2: Paolo Mofardin, Institut za povijest umjetnosti, Zagreb

3: digitalna presnimka iz kataloga izložbe: Ivan Meštrović. Skulpturen, Nationalgalerie, Staatliche Museen Preußischer Kulturbesitz, Berlin, 1987. (Nenad Gattin?)

5: Arhiv Galerije grada Praga / Archive of Prague City Gallery 